\title{
Empowering Development in the 21st Century: Energy - Growth - Environment Nexus in the Asia Pacific Region
}

\author{
Samantha Alyssa J. Acuin 1 (D), Mikaela Nicole S. Cabral² (D), Ronaldo R. Cabauatan*iD \\ ${ }^{1}$ College of Commerce of Business Administration, University of Santo Tomas, Manila, Philippines. \\ Email: samanthaalyssa.acuin.comm@ust.edu.ph \\ ${ }^{2}$ College of Commerce of Business Administration, University of Santo Tomas, Manila, Philippines. \\ Email: mikaelanicole.cabral.comm@ust.edu.ph \\ ${ }^{3}$ College of Commerce of Business Administration, University of Santo Tomas, Manila, Philippines; \\ Research Center for Social Sciences and Education, University of Santo Tomas, Manila, Philippines; \\ The Graduate School, University of Santo Tomas, Manila, Philippines. \\ Email: rrcabauatan@ust.edu.ph
}

CORRESPONDING
AUTHOR (*):
Ronaldo R. Cabauatan
(rrcabauatan@ust.edu.ph)
KEYWORDS:
Sustainable economy
Dynamic nexus
Economic growth
Energy consumption
CO2 emission
CITATION:
Acuin, S. A. J., Cabral, M. N. S., \& Cabauatan,
R. R. (2022). Empowering Development in
the 21 st Century: Energy - Growth -
Environment Nexus in the Asia Pacific
Region. Malaysian Journal of Social Sciences
and Humanities (MJSSH), 7(2), e001290.
https://doi.org/10.47405/mjssh.v7i2.1290

\begin{abstract}
This paper explores the dynamic nexus of non-renewable and renewable energy consumption, economic growth, urbanization, and FDI and its impact on carbon dioxide (CO2) emissions for thirteen (13) selected countries in the Asia Pacific region from 1960-2019 using panel OLS, cointegration, panel EGLS, cross-dependence tests, and pairwise granger causality tests. Empirical results proved the existence of the Environmental Kuznets Curve (EKC) and corroborate the subsistence of the Energy-Environmental Kuznets Curve (E-EKC) for thirteen (13) selected countries in the Asia Pacific region. Results from the pairwise granger causality test supported the conservation and neutrality hypothesis among the selected countries wherein the former showed a unidirectional causal relationship running from real GDP per capita to non-renewable energy consumption (GDP $\rightarrow$ NEC). Finally, this study provided possible recommendations to policymakers in developing effective carbon emission reduction and energy efficiency strategies for a sustainable economy to foster.
\end{abstract}

Contribution/Originality: This study contributes to the existing literature in the field of energy and environmental economics specifically in the understanding of the energygrowth-environment nexus, Environmental Kuznets Curve (EKC) hypothesis, EnergyEnvironmental Kuznets Curve (E-EKC) hypothesis, and Pollution-halo/-haven hypothesis in the Asia Pacific (APAC) region. This paper also provides new policy implications, interventions, and approaches that can ameliorate energy and environmental policies particularly in curtailing $\mathrm{CO} 2$ emissions without hampering economic growth.

\section{Introduction}

With the emergence of industrialization and pursuit for economic growth, greenhouse gas levels have been rapidly increasing over the past century primarily due to several human 
activities such as fossil fuel combustion, deforestation, energy production and consumption, and other industrial activities that involve emission of harmful air pollutants as by-products of the said activities particularly that of carbon dioxide (CO2), which in effect, is now the principal greenhouse gas that is significantly contributing to the worsening of global warming and climate change and is detrimental to both the ecology and the health of society at large. In recent data published by the BP Statistical Review of World Energy (2020a), the Asia Pacific (APAC) region has now caught up with its neighbouring regions as the largest $\mathrm{CO} 2$ emitter with a total volume of 17.27 billion metric tons emitted in 2019 with electricity and heat production as the leading sector contributing to the rising emissions. Moreover, according to the International Energy Agency (IEA) (2019), China alone, which has a robust economy, was deemed as the biggest emitter of $\mathrm{CO} 2$ emission from fossil fuel combustion with a share of about $30 \%$ of the world's total $\mathrm{CO} 2$ emissions that same year.

While energy plays a vital role for economic growth to foster and for society to function and carry out its daily activities such as cooking, driving, and manufacturing among others, it is one of the leading causes of the ever-increasing carbon dioxide emissions. Although collective efforts in reducing $\mathrm{CO} 2$ emission levels and investment in clean energies have been made as a way to address climate change, especially in achieving sustainability as promoted in the Sustainable Development Goals (SDGs) by the United Nations, emissions are projected to spike in the next few decades if left unmanaged and as developing countries pursue economic growth, efforts to curtail carbon emissions would have its own caveats such that countries would have to weigh which policies and regulations would help mitigate emission levels while supporting or without hampering economic growth. With that, the researchers' in the study further investigates the relationship of non-renewable (Coal, Oil, Natural Gas, and Diesel), and renewable energy consumption (Wind, Solar, Hydro, and Geothermal), economic growth, urbanization, and foreign direct investments and its dynamic impact on CO2 Emissions in a panel multivariate framework focused on 13 selected Asia Pacific (APAC) countries particularly: Australia, China, Hongkong, India, Indonesia, Japan, Malaysia, New Zealand, Philippines, Singapore, South Korea, Thailand, and Vietnam from 1960 to 2019.

\subsection{Status Report on Global Warming and Climate Change}

Global warming and climate change are just some of the environmental challenges that humankind is faced with in the grand scheme of things, wherein if the said issues are not addressed properly, either through reformations, policy changes, or regulations, such problems would certainly have an adverse effect in our society not just in the micro and global scale but also on a generational level as well. Moreover, due to the threat of rising global warming and climate change, effects that are widely evident in the Asia Pacific region are that of intensified floods, storms, and landslides among others. As mentioned, the region is already catching up with the rest of the world in terms of its contribution to greenhouse gas levels where in 2018, the region was responsible for about 35\% of energy related carbon emissions worldwide compared to its $17 \%$ share in 1990 and is projected to reach about $45 \%$ if left unregulated by the year 2030, especially without improvements in utilizing renewable energy as the main energy source (Regional Project Energy Security and Climate Change in Asia and Pacific Konrad-Adenauer-Stiftung, 2017). 


\subsection{Economic Growth and Development in the Asia Pacific Region}

From the emergence and rapid development of Asia Pacific countries in the past few decades, the region was able to sustain a high economic growth with China and India alone and has yet to surpass other emerging countries, despite having most of its member states in the developing stage. According to the Regional Economic Outlook: Asia Pacific released by the International Monetary Fund (IMF) (2018), without accounting for the current global pandemic, the Asia Pacific region was expected to grow by $5.5 \%$ that year, which would collectively be about two-thirds of global growth. As for the economic state of the Asia Pacific region in terms of nominal GDP, China ranked first and was able to generate about 14.34 trillion US dollars in 2019, followed by Japan with 5.08 trillion US dollars, and India with 2.87 trillion US dollars. While the region is flourishing and thriving especially in poverty reductions, lifting 1.1 billion people from extreme poverty since 1990, on the aspect of development as evaluated by the United Nations Development Programme (UNDP) (2020) on the Review of Multidimensional Poverty Index and Uses in Asia-Pacific, such economic growth has yet to be translated into sustained poverty reduction such that there is still a large portion of people struggling and are deprived in the non-income dimensions of poverty particularly in terms of health and education. Moreover, in the aspect of rapid urbanization, since half of the population in the region are living in the urban area, the ever-increasing urban poverty might be a challenge if not addressed properly and is expected to rise even further in 2050.

\subsection{Energy Landscape in the Asia Pacific Region}

As rapid economic growth prevails in the Asia Pacific region, demand for energy is evidently increasing especially in developing economies in the region as it is a vital component for economic prosperity to foster. According to the BP Statistical Review of World Energy (2020a), fossil fuels, particularly coal, continues to be the dominant source of energy heavily used in the region in terms of primary energy consumption by source, with China and India significantly driving energy consumption which accounts for about half of the increase in global demand for energy. It is projected that energy demand will rise to $60 \%$ by 2040 with coal and oil as the leading energy sources fuelling the region's power and transport sectors. In addition, with the high carbon emissions contributed by the electricity and heating production sector, energy efficiency and conservation policies have been formulated not only with the objective to curtail the ever-increasing emissions, but also that of encouraging countries in the region to utilize and invest more in clean and renewable energy sources instead of non-renewable such as fossil fuels. While energy derived from coal still dominates the overall energy mix, there have been significant improvements in the addition of renewable power sources across the region where renewables specifically hydropower, wind, solar, and geothermal have been utilized. In terms of electricity generation, Malaysia has the highest share for utilizing hydropower; Australia and India have the highest proportions for wind power; South Korea (38\%), Japan (19\%), and Thailand (17\%) have the highest share for solar power; and Singapore has the highest share (89\%) for geothermal power. Although energy consumption is relatively high compared to other neighbouring regions, about 1.3 billion people lack access to electricity worldwide with 622 million of them living in the Asia Pacific region (Regional Project Energy Security and Climate Change in Asia and Pacific KonradAdenauer-Stiftung, 2017). 


\subsection{Harnessing Clean Energy Towards Sustainability}

Although the current energy mix of most countries in the Asia Pacific region utilizes fossil fuels such as coal, oil, and natural gas as its main energy source, a transition from nonrenewable to clean and renewable energy sources is in progress. Over the past decade, renewable energy consumption has significantly increased from 93.2 to 419.6 mtoe (million metric tons of oil equivalent) worldwide, with the consumption in the Asia Pacific region rising from 92.2 to 144.5 mtoe, which accounts for about $34 \%$ of the world's renewable energy consumption (Asian Development Bank, 2019) While China is one of the leading countries in the region that has significantly contributed to the rising $\mathrm{CO} 2$ emissions, it is also one of the countries at the forefront of changing the energy landscape from fossil fuel dependency to harnessing more renewable energy sources and clean technologies such as hydropower, geothermal, and solar energy among others. In the pursuit of curtailing CO2 emissions by the year 2030, the Sustainable Development Goals (SDGs) developed by member states in the United Nations (UN) (2015) also provided a framework that would guide countries towards a more sustainable path that would not only support economic growth but also that of overall development. Among the targets presented, the researchers are focused on SDG 7 (Affordable and Clean Energy) and 13 (Climate Action) in the exploration of this study. Despite fossil fuel energy sources being relatively inexpensive compared to renewable technologies in generating electricity, costs for renewables such as solar photovoltaics (PV), concentrating solar power (CSP), onshore wind, and offshore wind have continuously declined by 82 percent, 47 percent, 40 percent, and 29 percent respectively throughout the decade and is expected to be new sources of electricity which are less expensive than the cheapest fossil fuel alternative (International Renewable Energy Agency (IRENA), 2020).

\subsection{Pioneering Works in the Energy-Growth-Environment Nexus}

Foundational studies in this field, particularly that of determining the causal relationship between energy consumption and economic growth, have been extensively introduced and discussed by Kraft and Kraft (1978) in their study, "On the Relationship Between Energy and GNP", from which during that time period, energy conservation was deemed as an unacceptable policy option for it would negatively affect economic activity, which also indicates that the direction of causality runs from energy consumption to economic growth and vice versa. Contrary to the notion, their findings showed that there is a unidirectional causality which only runs from GNP to energy consumption but not the other way around. These findings contradict such logical corollary as recent studies suggest that their results prove the conservation hypothesis wherein energy conservation policies designed to reduce energy consumption and wastes will not adversely affect economic growth, which in this case is GNP. One of the caveats in their study that most researchers in contemporary time have pointed out that, data obtained from that period could have substantially altered the results as there were years that included significant changes in the economy and historical events such as recessions brought about by the two world wars, rising energy prices, and oil embargo.

Studies investigating the energy-growth-environment nexus have paved its way into shaping environmental laws and policies, specifically that of curtailing $\mathrm{CO} 2$ emission levels in their respective countries with introducing energy conservation policies. However, knowing the differences in the energy landscapes of each country in varying years, certain studies, although have made consistent patterns, have yielded inconsistent and inconclusive results. 


\subsection{Problems Encountered}

Further studies in this field have emerged decades later as there was no clear consensus whether such results would suffice in proving the hypotheses and in extension, implementing and developing effective energy policy changes, for there have been several possible problems in interpreting the results. Apergis and Payne $(2009,2010)$ claimed that some of the problems that has contributed to the absence of a clear consensus include, (1) the heterogeneity in climate conditions across observed countries, (2) varying energy consumption patterns, (3) structural changes and different stages of economic development within a country, (4) alternative econometric methodologies employed in the study, (5) varying time periods, and (6) presence of omitted variable bias as referenced to the findings of Lütkepohl (1982) on "Non-causality due to omitted variables".

Most of the studies prevalent in this field have only focused on the bivariate relationship between energy and income which most researchers have pointed out that it should be examined in a trivariate or multivariate framework to prevent the possibility of omitted variable bias. Another problem in pursuing such a topic was that most single-country studies that have examined the relationship between income and environment rarely found evidence proving the EKC hypothesis for $\mathrm{CO} 2$ related pollutants, therefore it was recommended that a panel data for cross-countries should be employed (Arouri et al., 2012). In addressing the problem of heterogeneity and to overcome bias, cross-section dependence (CD) test must be employed with rejecting the null hypothesis of an existence of cross-section independence and homogeneity such that if tests were not demonstrated, it would cause severe size distortions in the results hence invalidating further estimations and inferences in the study (Hamit-Haggar, 2012).

Most results, especially in the study of Arouri et al. (2012), have shown an inverted Ushaped curve but due to the position of the threshold or that the turning points were either very low or high, it provided poor evidence to support the EKC hypothesis. Most of the literature review also revealed that there was no consensus concerning the existence and the direction of causality between energy consumption and economic growth as studies have varying methods and variables employed. Lastly, only a handful of studies were able to differentiate and include the impacts of non-renewable and renewable energy to $\mathrm{CO} 2$ Emissions such that most studies focused on non-renewable energy due to lack of data available for panel cross-country analysis.

This research aims to identify whether there exists a significant short-and long-run relationship and causal relationship between the independent variables: economic growth, energy consumption, urbanization, and foreign direct investment and dependent variable, $\mathrm{CO} 2$ emission. The paper also aims to investigate whether the Pollution-Haven or -Halo hypothesis, energy-growth-environment nexus, and the Environmental Kuznets Curve (EKC) and Energy Environmental Kuznets Curve (E-EKC) hypothesis exists in the Asia Pacific (APAC) Region particularly for: Australia, China, Hongkong, India, Indonesia, Japan, Malaysia, New Zealand, Philippines, Singapore, South Korea, Thailand, and Vietnam. Recognizing these correlations and causal relationships could serve as a guideline in policy making by determining how the independent variables would impact CO2 emissions and vice versa. In line with that, the researchers would also like to determine if harnessing renewable energy would be a viable solution in mitigating and curtailing CO2 emissions through various approaches without hampering economic growth, especially with sustainability at the end in mind. 


\section{Literature Review}

\subsection{Environmental Kuznets Curve (EKC) Hypothesis}

The Environmental Kuznets Curve (EKC) hypothesis pioneered by Kuznets (1956) claims that at the initial stage of economic development, as income level increases, environmental degradation increases as well, but beyond a certain level of income, the trend reverses from which high-income levels would then lead to environmental improvement. Such a relationship implies that environmental impacts or, in this study, CO2 emissions per capita are an inverted U-shaped function of GDP per capita. Since the EKC hypothesis was proposed, several empirical studies made in different countries have attempted to scrutinize the relationship between economic growth and environmental quality. Chng (2019) reiterated that despite several trials and repetitive studies made, such hypotheses' validation is still inconclusive because the variation of the results remain inconsistent, or the results vary from one study to another. Such inconsistency is mainly attributed to the differences in the variables, countries, period, and models employed (Ahmad et al., 2017). Even so, this hypothesis has made a strong foundation on how economic growth and environmental degradation are correlated. Studies from Apergis and Payne (2010), Saboori, Sulaiman and Mohd (2012), Al-Mulali and Ozturk (2015), Ummalla and Goyari (2021) proved the existence of EKC in their respective studies while Iwata, Okada, and Samreth (2012) and Baek (2015) disproved the EKC hypothesis.

\subsection{Energy-Environmental Kuznets Curve (E-EKC) Hypothesis}

Deriving from the EKC hypothesis, the Energy-Environmental Kuznets Curve (E-EKC) hypothesis is focused on the relationship between economic growth and energy consumption or use. The hypothesis claims that as income level increases, energy consumption also increases up to a certain level, but beyond a certain income level this trend also reverses, which leads to an improvement in energy efficiency as illustrated in an inverted U-shaped curve similar to that of the EKC hypothesis. Most of the studies found under E-EKC says that the curve arises under the hypothesis that there is an increasing relationship between environmental pressure and economic growth to income per capita, and further increase in income will lead to improved environmental quality (Chowdhury \& Moran, 2012) . Several researchers investigated the relationship between energy consumption, economic growth also assessed the existence of E-EKC in different countries with studies from Sarkodie and Ozturk (2020), Shahbaz, Lean and Shabbir (2012) , Xia and Wang (2020) , Pablo-Romero \& Sánchez-Braza (2017) , Sinaga, Alaeddin, and Jabarullah (2019), and Aruga (2019) proving the existence of the E-EKC hypothesis. However, there were some studies that provided mixed results in the existence of E-EKC and the dissociating relationship between energy consumption and economic growth. According to Hsiao et al. (2007) and Shahbaz et al. (2017), one possible reason for these mixed results is that most of the researchers rely on parametric techniques to validate the relationship between such variables. To incorporate the nonlinearity of the E-EKC, they used parametric econometric methods to necessitate the linearization of its functional form. On the other hand, Shahbaz et al. (2017) used nonparametric techniques because they believed that it has several benefits over its parametric counterparts. 


\subsection{Nexus between Energy Consumption and C02 Emissions}

In understanding the nexus between Energy Consumption and CO2 emission, a unidirectional causality running from energy consumption to $\mathrm{CO} 2$ emission indicates that the former drives $\mathrm{CO} 2$ emission levels while a bi-directional or feedback causality running from both variables implies that an increase in energy consumption could lead to an increase in CO2 emission and vice versa. Studies from Alam et al. (2011), Antonakakis Chatziantoniou and Filis (2017), Wasti and Zaidi (2020), Mirza and Kanwal (2017) have investigated such nexus with varying methods employed found a bi-directional causality in energy consumption and $\mathrm{CO} 2$ emission while a unidirectional causality running from energy consumption to $\mathrm{CO} 2$ emission was proved in the studies of Joo, Kim, and Yoo (2015), Sulaiman (2014), Rahman and Majumder (2020).

\subsection{Pollution-Haven and Pollution-Halo Hypothesis}

In the study of Cole (2004), he claimed that the difference between the environmental policies in developing and developed countries may be intensifying the shifting away from manufacturing of the developed countries while the developing countries are specializing in pollution-intensive manufacturing sectors. The original pollution haven hypothesis by Copeland and Taylor (1994) states that as trade opens up, pollution-intensive industries shift from rich countries that implement strict environmental policies to emerging countries with weak policies. In addition to this, it is believed that those remaining as clean industries move towards the rich countries. This hypothesis assumes that it is cheaper to produce pollution-intensive goods in countries with less stringent environmental policies that are usually in poor countries and trade combined with differences of how strong the environmental policy is, creates a pollution haven in most of the poorer countries (Kheder \& Zugravu, 2008). In a research made by Yoon and Heshmati (2020), they investigated the impact of environmental regulations on foreign direct investment (FDI) to verify the pollution haven hypothesis. The result of their investigation shows that the stricter the policies in host countries that are located in Asia, the lower the FDI in both intensive and extensive to those Asian countries. It supports the occurrence of the pollution haven hypothesis. However, they also stated that the environmental regulations on FDI are hindered by the FDI in the non-production part. In other works of literature about this hypothesis, they claim that the evidence for pollution havens is relatively weak at best and inconclusive; they also described it even as negative at worst (Neumayer, 2001).

On the other hand, Mert and Caglar (2020) stated in their study that the pollution halo hypothesis claims that investor firms who came from the developed countries play a vital role in the reduction of carbon emissions in the host country because the type of production structure that the investors are using relies heavily on green technology unlike the existing type of production used by the host country. They also explained that the difference between pollution-haven and pollution halo is that the pollution haven hypothesis claims that foreign direct investment would cause an increase in $\mathrm{CO} 2$ emissions while in pollution halo suggests that foreign direct investment would decrease CO2 emissions. A study conducted by Bu and Wagner (2016) speaks of preferences in the United States firms to select Chinese provinces for investments. They mentioned that those with environmentally friendly technology firms choose to invest in regions with rigorous Environmental policy, while those firms that have a low-end technology avoid selecting regions that are highly regulated for investment. 
Studies from Yoon and Heshmati (2020), Naz et al. (2018); Shahbaz, Balsalobre-Lorente, and Sinha (2019), Essandoh, Islam and Kakinaka (2020), Adeel-Farooq, Riaz and Ali (2021), Rahman, Cai and Ahmad (2019) showed and confirmed that FDI positively affects CO2 emissions in support of the pollution-haven hypothesis while studies from Zhou et al. (2018), Repkine and Min (2020), Hao and Liu (2015), Zhang and Zhou (2016), Öztürk and Öz (2016) showed that FDI negatively affects CO2 emissions proving the pollution halo hypothesis.

\subsection{Nexus between Energy Consumption and Economic Growth}

The growth hypothesis postulates that energy consumption plays a significant role in economic growth which implies that conservation policies which reduce energy consumption may adversely affect economic growth. Studies from Bozoklu and Yilanci (2013), Yildirim, Saraç and Aslan (2012), Shahbaz, Khan and Tahir (2013), Mbarek, Saidi and Rahman (2017) confirmed the growth hypothesis of a unidirectional causal relationship running from energy consumption to economic growth $(E C \rightarrow E G)$. On the other hand, the conservation hypothesis postulates otherwise and that energy conservation policies which are designed to reduce energy consumption will not adversely impact economic growth. Studies from Ozturk, Aslan and Kalyoncu (2010), Kahia, Omri and Jarraya (2021), Munir, Lean and Smyth (2020) supported the conservation hypothesis of a unidirectional causal relationship running from economic growth to energy consumption $(\mathrm{EG} \rightarrow \mathrm{EC}$ ). In addition, the feedback hypothesis postulates that there is a bidirectional causal relationship between energy consumption and economic growth which implies that energy conservation policies that reduce carbon emissions may not adversely impact economic growth. Studies from Sebri and Ben-Salha (2014), Shahbaz et al. (2015), Cabauatan and Tatlonghari (2017), Chen et al. (2019), Munir, Lean and Smyth (2020), Abdollahi (2020) supported the Feedback hypothesis with a bidirectional causal relationship between economic growth and energy consumption. Lastly, the neutrality hypothesis postulates that there is no significant causal relationship between energy consumption and economic growth which implies that neither growth nor energy conservation policies would have any adverse effects on economic growth. Studies from Zerbo (2015), Magazzino (2016a, 2016b), Ozcan dan Ozturk (2019) confirmed the hypothesis that there is a neutral relationship between energy consumption and economic growth.

\subsection{Nexus between Urbanization and $\mathrm{CO2}$ Emissions}

In investigating the relationship between urbanization and $\mathrm{CO} 2$ emissions with the former as a means in curtailing the latter, several studies have been conducted with varying results. According to a study conducted by Wang et al. (2019); urbanization positively influences $\mathrm{CO} 2$ emissions for APEC countries such that empirical evidence showed that a $1 \%$ increase in urbanization, increases CO2 emissions by $0.274 \%$. This positive association is due to the migration of the population from the rural areas to the urban areas that is said to create problems with the provision of utilities and services which then contribute to environmental degradation and pollution. Studies from Liddle (2013), Xu \& Lin (2015a, 2015b), and Pata (2017) also support the positive significant impacts of urbanization on CO2 emissions, while Sharma (2011) and Hossain (2011) showed negative significant impacts of urbanization on carbon emissions.

\subsection{Key Assumptions}


Following the results of the majority of the studies in the literature review, the expected relationship of the independent variables with respect to the dependent variable, $\mathrm{CO} 2$ emission, are as follows: Non-renewable energy consumption, foreign direct investment (FDI), urbanization, and economic growth in terms of GDP per capita positively impacts CO2 emissions, which means that as non-renewable energy consumption, FDI, urbanization, and GDP per capita increases, $\mathrm{CO} 2$ emission is expected to increase. On the other hand, renewable energy consumption and the quadratic terms of economic growth (GDP squared) negatively impacts $\mathrm{CO} 2$ emissions, which means that as renewable energy consumption and GDP per capita squared increases, CO2 emission is expected to decrease. Coefficients of non-renewable energy consumption, GDP per capita, urbanization, and foreign direct investment are expected to be greater than zero or positive while coefficients for renewable energy consumption and GDP squared are expected to be less than zero or negative. The summary of all the results of the respective studies is shown in Table 1.

Table 1: Summary of Literature Review

\begin{tabular}{|c|c|c|c|c|}
\hline Author(s) & Countries & Period & Methodology & Main Conclusion \\
\hline \multicolumn{5}{|c|}{ Environmental Kuznets Curve (EKC) Hypothesis } \\
\hline $\begin{array}{l}\text { Apergis \& Payne } \\
(2009)\end{array}$ & Central America & $1971-2014$ & IPS, PCO, PGC & EKC \\
\hline $\begin{array}{l}\text { Saboori, Sulaiman, } \\
\& \text { Mohd (2012) }\end{array}$ & Malaysia & $1980-2009$ & ARDL & EKC \\
\hline $\begin{array}{l}\text { Iwata, Okada, \& } \\
\text { Samreth (2012) }\end{array}$ & $\begin{array}{l}11 \text { OECD } \\
\text { Countries }\end{array}$ & $\begin{array}{l}\text { Varying time } \\
\text { periods }\end{array}$ & ADF, ARDL & Non-EKC \\
\hline Baek (2015) & $\begin{array}{l}12 \text { major nuclear } \\
\text { generating } \\
\text { countries }\end{array}$ & $1980-2009$ & $\begin{array}{l}\text { LLC, IPS, PCO, FMOLS, } \\
\text { DOLS }\end{array}$ & Non-EKC \\
\hline $\begin{array}{l}\text { Al-Mulali \& Ozturk } \\
\text { (2015) }\end{array}$ & 93 countries & $1980-2008$ & $\begin{array}{l}\text { Panel unit root test; } \\
\text { GMM }\end{array}$ & EKC \\
\hline $\begin{array}{l}\text { Ummalla \& Goyari } \\
(2021)\end{array}$ & BRICS countries & $1992-2014$ & $\begin{array}{l}\text { Granger causality Panel } \\
\text { cointegration }\end{array}$ & EKC \\
\hline \multicolumn{5}{|c|}{ Energy-Environmental Kuznets Curve (E-EKC) Hypothesis } \\
\hline $\begin{array}{l}\text { Pablo-Romero \& } \\
\text { Sanchez-Braza } \\
(2017)\end{array}$ & EU-28 countries & $1990-2013$ & $\begin{array}{l}\text { cross-section } \\
\text { dependence, unit root } \\
\text { and cointegration tests }\end{array}$ & E-EKC \\
\hline Aruga (2019) & $\begin{array}{l}19 \text { Asia-pacific } \\
\text { countries }\end{array}$ & $1984-2014$ & $\begin{array}{l}\text { Panel regression and } \\
\text { panel cointegration }\end{array}$ & E-EKC \\
\hline Xia \& Wang (2020) & China & $1965-2016$ & $\begin{array}{l}\text { Unit root and } \\
\text { cointegration tests }\end{array}$ & E-EKC \\
\hline $\begin{array}{l}\text { Sinaga, Alaeddin, \& } \\
\text { Jabarullah (2019) }\end{array}$ & Malaysia & $1978-2016$ & ARDL & E-EKC \\
\hline $\begin{array}{l}\text { Shahbaz, Lean, \& } \\
\text { Shabbir (2012) }\end{array}$ & Pakistan & 1971-2009 & $\begin{array}{l}\text { Cointegration and } \\
\text { Granger causality }\end{array}$ & E-EKC \\
\hline $\begin{array}{l}\text { Sarkodie \& Ozturk } \\
(2020)\end{array}$ & Kenya & $1971-2013$ & Unit root; ARDL & E-EKC \\
\hline \multicolumn{5}{|c|}{ Nexus between Energy Consumption and $\mathrm{CO} 2$ Emission } \\
\hline Sulaiman (2014) & Nigeria & $1970-2010$ & $\begin{array}{l}\text { Toda and Yamamoto's } \\
\text { Approach }\end{array}$ & $\mathrm{EC} \rightarrow \mathrm{CO} 2$ \\
\hline $\begin{array}{l}\text { Rahman \& } \\
\text { Majumder (2020) }\end{array}$ & $\begin{array}{l}\text { Industrialized } \\
\text { countries }\end{array}$ & $1980-2014$ & DOLS and FMOLS & $\mathrm{EC} \rightarrow \mathrm{CO} 2$ \\
\hline $\begin{array}{l}\text { Ozturk \& Salah } \\
\text { Uddin (2012) }\end{array}$ & India & 1971-2007 & ADF and PP & $\mathrm{EC} \leftrightarrow \mathrm{CO} 2$ \\
\hline
\end{tabular}




\begin{tabular}{|c|c|c|c|c|}
\hline $\begin{array}{l}\text { Antonakakis, } \\
\text { Chatziantoniou, \& } \\
\text { Filis (2017) }\end{array}$ & 106 countries & 1971- 2011 & $\begin{array}{l}\text { PVAR \& Granger } \\
\text { causality }\end{array}$ & $\mathrm{EC} \leftrightarrow \mathrm{CO} 2$ \\
\hline Alam et al. (2011) I & India & $1971-2006$ & $\begin{array}{l}\text { IAA, Dynamic modeling } \\
\text { approach, Granger } \\
\text { causality }\end{array}$ & $\mathrm{EC} \leftrightarrow \mathrm{CO} 2$ \\
\hline $\begin{array}{l}\text { Wasti, \& Zaidi } \\
(2020)\end{array}$ & Kuwait & $1971-2017$ & ARDL & $\mathrm{EC} \leftrightarrow \mathrm{CO} 2$ \\
\hline \multicolumn{5}{|c|}{ Pollution-Haven and Pollution-Halo Hypothesis } \\
\hline $\begin{array}{l}\text { Shahbaz, } \\
\text { Balsalobre-Lorente, } \\
\text { \& Sinha (2019) }\end{array}$ & MENA countries & $1990-2015$ & GMM & $\begin{array}{l}\text { Pollution haven } \\
\text { hypothesis }\end{array}$ \\
\hline $\begin{array}{l}\text { Essandoh, Islam, \& } \\
\text { Kakinaka. (2020) }\end{array}$ & $\begin{array}{l}52 \text { developed \& } \\
\text { developing } \\
\text { countries }\end{array}$ & $1991-2014$ & PMG-ARDL & $\begin{array}{l}\text { Pollution haven } \\
\text { hypothesis }\end{array}$ \\
\hline $\begin{array}{l}\text { Rahman, Cai, \& } \\
\text { Ahmad (2019) }\end{array}$ & $\begin{array}{l}\text { China, India, } \\
\text { Philippines, } \\
\text { Pakistan, } \\
\text { Bangladesh, and } \\
\text { Sri Lanka }\end{array}$ & $1982-2014$ & ARDL & $\begin{array}{l}\text { Pollution haven \& } \\
\text { Pollution halo } \\
\text { hypothesis }\end{array}$ \\
\hline $\begin{array}{l}\text { Zhang \& Zhou } \\
(2016)\end{array}$ & China & $1995-2010$ & STIRPAT & $\begin{array}{l}\text { Pollution halo } \\
\text { hypothesis }\end{array}$ \\
\hline Öztürk, \& Öz (2016)’ & Turkey & $1974-2011$ & $\begin{array}{l}\text { cointegration and } \\
\text { Granger causality }\end{array}$ & $\begin{array}{l}\text { Pollution halo } \\
\text { hypothesis }\end{array}$ \\
\hline Hao \& Liu (2015) & $\begin{array}{l}29 \text { provinces in } \\
\text { China }\end{array}$ & $1995-2011$ & $\begin{array}{l}\text { Halkos and Paizanos } \\
\text { Approach }\end{array}$ & $\begin{array}{l}\text { Pollution halo } \\
\text { hypothesis }\end{array}$ \\
\hline \multicolumn{5}{|c|}{ Nexus between Energy Consumption and Economic Growth } \\
\hline $\begin{array}{l}\text { Ozturk \& Acaravci } \\
(2010)\end{array}$ & 51 countries & $1971-2005$ & $\begin{array}{l}\text { Pedroni panel } \\
\text { cointegration, FMOLS, } \\
\text { DOLS, and panel causality } \\
\text { tests }\end{array}$ & $\begin{array}{l}\text { Conservation \& } \\
\text { Feedback } \\
\text { hypothesis }\end{array}$ \\
\hline $\begin{array}{l}\text { Shahbaz, Khan, \& } \\
\text { Tahir (2013) }\end{array}$ & China & $1971-2011$ & $\begin{array}{l}\text { ARDL, Johansen and } \\
\text { Juselies test; VECM, } \\
\text { granger causality }\end{array}$ & $\begin{array}{l}\text { Growth } \\
\text { hypothesis }\end{array}$ \\
\hline $\begin{array}{l}\text { Sebri \& Ben-Salha } \\
(2014)\end{array}$ & BRICS countries & 1971-2010 & ARDL, VECM & $\begin{array}{l}\text { Feedback } \\
\text { hypothesis }\end{array}$ \\
\hline $\begin{array}{l}\text { Shahbaz et al. } \\
(2015)\end{array}$ & Pakistan & $1972-2011$ & ARDL, RWA cointegration & $\begin{array}{l}\text { hFeedback } \\
\text { hypothesis }\end{array}$ \\
\hline Zerbo (2015) & $\begin{array}{l}8 \text { Sub- Saharan } \\
\text { countries }\end{array}$ & $1971-2010$ & $\begin{array}{l}\text { ARDL, Pesaran, Shin and } \\
\text { Smith Cointegration test, } \\
\text { Toda and Yamamoto } \\
\text { Granger causality test }\end{array}$ & $\begin{array}{l}\text { Neutrality } \\
\text { hypothesis }\end{array}$ \\
\hline Magazzino (2016a) 1 & $\begin{array}{l}10 \text { Middle East } \\
\text { countries }\end{array}$ & 1971-2006 & Panel VAR approach & $\begin{array}{l}\text { Growth \& } \\
\text { Neutrality } \\
\text { hypothesis }\end{array}$ \\
\hline $\begin{array}{l}\text { Cabauatan \& } \\
\text { Tatlonghari (2017) }\end{array}$ & Philippines & 1974-2014 & $\begin{array}{l}\text { Cointegration Tests, } \\
\text { VECM Granger Causality }\end{array}$ & $\begin{array}{l}\text { Feedback } \\
\text { hypothesis }\end{array}$ \\
\hline $\begin{array}{l}\text { Mbarek, Saidi, \& } \\
\text { Rahman (2017) }\end{array}$ & Tunisia & 1990-2015 & $\begin{array}{l}\text { Granger causality test \& } \\
\text { VECM model }\end{array}$ & $\begin{array}{l}\text { Growth } \\
\text { hypothesis }\end{array}$ \\
\hline Chen et al. (2019) & 3 regions in China & $1995-2012$ & $\begin{array}{l}\text { FMOLS, DOLS, Panel } \\
\text { causality tests }\end{array}$ & $\begin{array}{l}\text { Feedback } \\
\text { hypothesis }\end{array}$ \\
\hline $\begin{array}{l}\text { Ozcan \& Ozturk } \\
(2019)\end{array}$ & $\begin{array}{l}16 \text { emerging } \\
\text { countries }\end{array}$ & $1990-2016$ & $\begin{array}{l}\text { Bootstrap panel causality } \\
\text { test }\end{array}$ & $\begin{array}{l}\text { Neutrality } \\
\text { hypothesis }\end{array}$ \\
\hline Abdollahi (2020) & $\begin{array}{l}8 \text { developing } \\
\text { countries }\end{array}$ & 1998-2011 & $\begin{array}{l}\text { Spatial Autoregressive } \\
\text { Model Estimation }\end{array}$ & $\begin{array}{l}\text { Feedback } \\
\text { hypothesis }\end{array}$ \\
\hline
\end{tabular}




\begin{tabular}{|c|c|c|c|c|}
\hline $\begin{array}{l}\text { Munir, Lean, \& } \\
\text { Smyth (2020) }\end{array}$ & $\begin{array}{l}\text { ASEAN-5 } \\
\text { countries }\end{array}$ & $1980-2016$ & $\begin{array}{l}\text { Granger Causality test, } \\
\text { Cross-Sectional } \\
\text { Dependence test }\end{array}$ & $\begin{array}{l}\text { Feedback \& } \\
\text { Conservation } \\
\text { hypothesis }\end{array}$ \\
\hline $\begin{array}{l}\text { Kahia, Omri, \& } \\
\text { Jarraya (2021) }\end{array}$ & OECD economies & $1990-2016$ & Hansen test \& DWH test & $\begin{array}{l}\text { Conservation } \\
\text { hypothesis }\end{array}$ \\
\hline \multicolumn{5}{|c|}{ Nexus between Urbanization and C02 Emission } \\
\hline Wang et al. (2019) & APEC Countries & $1990-2014$ & $\begin{array}{l}\text { CD test, Panel } \\
\text { Cointegration test, DSUR, } \\
\text { Pairwise causality test }\end{array}$ & $\begin{array}{l}\text { URB Positively } \\
\text { Impacts CO2 }\end{array}$ \\
\hline Liddle (2013) & \multicolumn{3}{|c|}{ Summary Review of 28 Related Papers } & $\begin{array}{l}\text { URB Positively } \\
\text { Impacts CO2 }\end{array}$ \\
\hline $\mathrm{Xu} \& \operatorname{Lin}(2015 \mathrm{a})$ & $\begin{array}{l}30 \text { administrative } \\
\text { areas in China }\end{array}$ & $1990-2011$ & $\begin{array}{l}\text { Nonparametric additive } \\
\text { regression models, IPAT, } \\
\text { Panel Cointegration tests }\end{array}$ & $\begin{array}{l}\text { URB Positively } \\
\text { Impacts CO2 }\end{array}$ \\
\hline Pata (2017) & Turkey & $1974-2013$ & $\begin{array}{l}\text { ARDL bounds test, } \\
\text { FMOLS, } \\
\text { cointegration tests }\end{array}$ & $\begin{array}{l}\text { URB Positively } \\
\text { Impacts CO2 }\end{array}$ \\
\hline Sharma (2011) & 69 countries & $1985-2005$ & Panel OLS & $\begin{array}{l}\text { URB Negatively } \\
\text { Impacts CO2 }\end{array}$ \\
\hline Hossain (2011) & $\begin{array}{l}\text { Newly } \\
\text { Industrialized } \\
\text { Countries }\end{array}$ & $1971-2007$ & $\begin{array}{l}\text { Panel Cointegration and } \\
\text { Granger Causality }\end{array}$ & $\begin{array}{l}\text { URB Negatively } \\
\text { Impacts CO2 }\end{array}$ \\
\hline
\end{tabular}

\section{Methodology}

\subsection{Conceptual Framework}

Figure 1 shows the research simulacrum which was formulated from the amalgamation of studies from Akram et al. (2020), Apergis and Payne (2009, 2010), Hossain (2011), Arouri et. al (2012), Hamit-Haggar (2012), Zakarya et al. (2015), and Wang et al. (2019) as mentioned in the key assumptions in the literature which were then modified in specification for this study.

Figure 1: Research Simulacrum

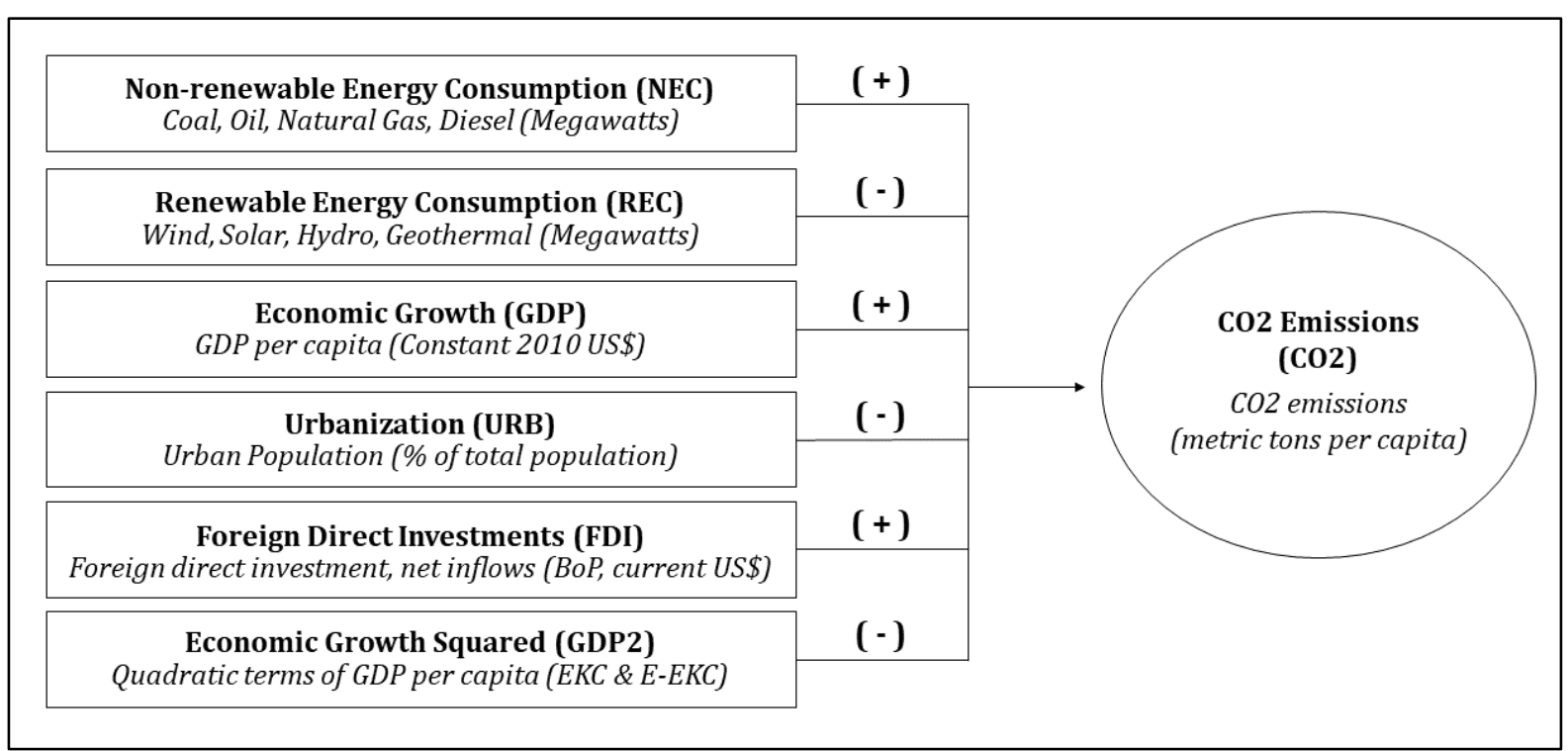




\subsection{Research Method}

The research design used in this paper is quantitative and descriptive in nature wherein it analyzes and investigates the statistical relationship among the variables. This research design is used in almost all studies that investigates the energy-growth-environment nexus. Similar to the study of Kozul-Wright and Fortunato (2012), which is a descriptive research, they used panel data analysis to determine the significant direct and indirect effects of trade on $\mathrm{CO} 2$ emissions in 12 MENA countries. The purpose of these types of studies is to discuss the effectiveness of emission reduction policies and provide some environmental and trade policy proposals connected with the results that the researchers acquired in the study (Alam, 2014). The researchers used the EViews software as their primary statistical tool to perform the following tests, econometric model, and analysis in the pursuit of study. To fully understand the relationship of each variable present in this study, the researchers conducted and performed panel least squares, pairwise granger causality tests, and panel cross-section and period heteroskedasticity tests with panel EGLS.

Such models and variables are subjected to cautionary tests to validate the suitability of the variables to the model namely: (1) Augmented Dickey-Fuller (ADF) test to assess the unit roots of the time series data; (2) Optimal Lag Length (Akalke Information Criterion and Schwarz Information Criterion) to experiment and determine the sufficient and appropriate number of lags in the model; (3) Structural Stability test to determine whether the coefficients of the regression model is stable and can be used for policy analysis and forecasting; (4) Test for Heteroskedasticity Disturbances to detect whether the parameters are suitable and not biased and inefficient and to detect the presence of heteroskedasticity disturbances in the residuals with the White's Heteroskedasticity employed; (5) Johansen Cointegration test to determine whether there exists a cointegration among the variables and such hypothesized relationships are not spurious; (6) Specification Error test to test whether non-linear combinations of independent variables help in explaining the dependent variable and to determine if there is no misspecification error in the data; and (7) Cross-section Dependence test to test whether the data is cross-sectionally correlated and if there are size distortions and disturbances in the panel data.

\subsection{Econometric Model}

Similar to the studies of Dogan and Aslan (2017), Bilgili, Koçak, and Bulut (2016), this paper used the following function wherein carbon dioxide (CO2) emission is the dependent variable while Non-renewable Energy Consumption (NEC), Renewable Energy Consumption (REC), Economic Growth (GDP), Quadratic terms of economic growth (GDP2), Urbanization (URB), and Foreign Direct Investment (FDI) are the independent variables:

$$
C O 2_{i t}=\alpha_{i t}+\beta_{1} N E C_{i t}+\beta_{2} R E C_{i t}+\beta_{3} G D P_{i t}+\beta_{4} G D P_{i t}^{2}+\beta_{5} U R B_{i t}+\beta_{6} F D I_{i t}+e_{i t}
$$

Wherein the subscripts $i$ and $t$ pertains to the country and time respectively. The variables used in this study are measured as follows. $\mathrm{CO} 2$ is carbon dioxide emissions in metric tons per capita; NEC is non-renewable energy consumption from Coal, Oil, Natural Gas, and Diesel in Megawatts (MW); REC is renewable energy consumption from Wind, Solar, Hydro, and Geothermal in Megawatts (MW); GDP is GDP per capita (constant 2010 US\$); $G D P 2$ is real GDP per capita squared; $U R B$ is urbanization in terms of urban population (\% 
of total population); and FDI is foreign direct investments (in terms of net inflows, current US\$).

\subsection{Data Collection Techniques}

Table 2 shows the data set collected from the World Bank Open Data and the BP Statistical Review of World Energy (2020b) from 13 selected Asia Pacific (APAC) countries particularly: Australia, China, Hongkong, India, Indonesia, Japan, Malaysia, New Zealand, Philippines, Singapore, South Korea, Thailand, and Vietnam from 1960 to 2019 because of the completeness of their data. The researchers also converted the data collected from the BP Statistical Review of World Energy (2020b), specifically for the variables nonrenewable and renewable energy consumption, from Exajoules to Megawatts (MW) as the latter is the standard measurement used in energy-related industries.

Table 2: Data Presentation

\begin{tabular}{|c|c|c|c|}
\hline Variables & Indicators & Period & Data Source \\
\hline CO2 Emissions (CO2) & $\begin{array}{l}\text { CO2 emissions } \\
\text { (metric tons per capita) }\end{array}$ & $1960-2016$ & World Bank \\
\hline Economic Growth (GDP) & $\begin{array}{l}\text { GDP per capita } \\
\text { (Constant } 2010 \text { US\$) }\end{array}$ & $1960-2019$ & World Bank \\
\hline $\begin{array}{l}\text { Non-Renewable Energy } \\
\text { Consumption (NEC) }\end{array}$ & $\begin{array}{l}\text { Coal, Oil, Natural Gas, and } \\
\text { Diesel (Megawatts) }\end{array}$ & $1965-2019$ & $\begin{array}{l}\text { BP Statistical } \\
\text { Review of World } \\
\text { Energy }\end{array}$ \\
\hline $\begin{array}{l}\text { Renewable Energy } \\
\text { Consumption (REC) }\end{array}$ & $\begin{array}{l}\text { Wind, Solar, Hydro, } \\
\text { Geothermal } \\
\text { (Megawatts) }\end{array}$ & $1965-2019$ & $\begin{array}{l}\text { BP Statistical } \\
\text { Review of World } \\
\text { Energy }\end{array}$ \\
\hline Urbanization & $\begin{array}{l}\text { Urban Population } \\
\text { (\% of Total Population) }\end{array}$ & $1960-2019$ & World Bank \\
\hline $\begin{array}{l}\text { Foreign Direct Investments } \\
\text { (FDI) }\end{array}$ & $\begin{array}{l}\text { Foreign Direct Investments } \\
\text { net inflows (current US\$) }\end{array}$ & $1970-2019$ & World Bank \\
\hline
\end{tabular}

Source: World Bank and BP Statistical Review of World Energy

According to the official definitions of the data obtained from the World Bank, CO2 emission (metric tons per capita) is defined as those stemming from the burning of fossil fuels and the manufacture of cement which include carbon dioxide produced during consumption of solid, liquid, and gas fuels and gas flaring. Second, urban population $\%$ of total population) refers to people living in urban areas. Third, GDP per capita is based on constant 2010 US\$ and is the gross domestic product divided by midyear population. Fourth, foreign direct investment (FDI) refers to direct investment equity flows in the reporting economy. Fifth, non-renewable energy consumption in this study is composed of energy used from coal, diesel, natural gas, and oil (Megawatts) while renewable energy consumption is composed of energy used from hydro, solar, geothermal, and wind (Megawatts).

\section{Results and Discussion}

In investigating the short-run and long-run relationship and causal relationship between the dependent and independent variables, the following estimation techniques were employed specifically utilizing, panel least squares, panel cointegration test, pairwise granger causality test, cross-section dependence test, and panel cross-section and period heteroskedasticity tests with panel EGLS. 
The results for the panel least squares presented in Table 3 showed that all variables except for Urbanization and Log of GDP per capita are statistically significant. Moreover, Log of non-renewable energy consumption and real GDP per capita, FDI, and real GDP per capita squared positively affects $\mathrm{CO} 2$ per capita while Log of Renewable energy consumption and urbanization negatively affects CO2 per capita. Considering the statistically significant figures, as a result for every one (1) unit increase in CO2 per capita there will be an increase of 0.978 for non-renewable energy, 3.05E-11 for FDI, 0.975 for real GDP per capita, and 3.64E-09 for real GDP per capita squared. On the other hand, there will be a decrease of 1.906 for renewable energy, and 0.005 for urbanization for every one (1) unit increase in CO2 per capita. Since FDI positively affects CO2 emissions, it implies the existence of pollution haven in this study. This supports the claims of Naz et al. (2018), Shahbaz, Balsalobre-Lorente, and Sinha (2019), Essandoh, Islam, and Kakinaka (2020), and Rahman, Cai, and Ahmad (2019). It was clear that pollution-halo does not exist in those selected Asia Pacific countries.

Table 3: Panel Least Squares

\begin{tabular}{|c|c|c|c|c|}
\hline \multicolumn{5}{|c|}{ Dependent Variable: C02 per capita } \\
\hline Variable & Coefficient & Std. Error & t-Statistic & Prob. \\
\hline Constant & 16.93911 & 5.894796 & 2.87357 & 0.0046 \\
\hline LOG Non-renewable energy (NEC) & 0.978045 & 0.146439 & 6.678846 & 0.0000 \\
\hline Foreign Direct Investments (FDI) & $3.05 E-11$ & $3.63 E-12$ & 8.394736 & 0.0000 \\
\hline LOG Renewable energy (REC) & -1.906284 & 0.174313 & -10.936 & 0.0000 \\
\hline LOG real GDP per capita (GDP) & 0.975766 & 0.543039 & 1.796862 & 0.0743 \\
\hline Urbanization (URB) & -0.005463 & 0.030552 & -0.178793 & 0.8583 \\
\hline Quadratic term of GDP (GDP2) & 3.64E-09 & $3.35 \mathrm{E}-10$ & 10.86495 & 0.0000 \\
\hline Root MSE & 1.686891 & R-squared & & 0.899883 \\
\hline Mean dependent var & 6.900486 & Adjusted R- & red & 0.896081 \\
\hline S.D. dependent var & 5.347521 & S.E. of regre & & 1.723854 \\
\hline Akaike info criterion & 3.9685 & Sum square & & 469.5244 \\
\hline Schwarz criterion & 4.100268 & Log likeliho & & -320.4013 \\
\hline Hannan-Quinn criterion & 4.021989 & F-statistic & & 236.6914 \\
\hline Durbin-Watson stat & 0.11724 & Prob(F-stat & & 0.000000 \\
\hline
\end{tabular}

Source: EViews Software

In Table 4, the Johansen Fisher trace and maximum eigenvalue cointegration tests reject the null hypothesis of "no cointegration". This indicates the existence of a long-run panel cointegration relationship between the dependent and independent variables. Based on these results, $\mathrm{CO} 2$ per capita could affect non-renewable energy, renewable energy, real GDP per capita, urbanization, and real GDP per capita squared in the long run. However, with the real GDP per capita squared positively affecting CO2 per capita instead of negatively, the existence of the EKC hypothesis is disproved.

Table 4: Johansen Fisher Panel Cointegration Test

\begin{tabular}{|c|c|c|c|c|}
\hline \multicolumn{5}{|c|}{ Series: C02 per capita + NEC + REC + FDI + GDP + URB + GDP2 } \\
\hline Hypothesized No. of CE(s) & $\begin{array}{l}\text { Fisher Stat.* } \\
\text { (from trace test) }\end{array}$ & Prob. & $\begin{array}{l}\text { Fisher Stat.* } \\
\text { (from max-eigen test) }\end{array}$ & Prol \\
\hline None & 181.8 & 0.0000 & 146.9 & 0.0000 \\
\hline At most 1 & 214.3 & 0.0000 & 107.1 & 0.0000 \\
\hline At most 2 & 155.5 & 0.0000 & 81.35 & 0.0000 \\
\hline At most 3 & 161.5 & 0.0000 & 104.8 & 0.0000 \\
\hline At most 4 & 87.5 & 0.0000 & 60.59 & 0.0000 \\
\hline
\end{tabular}




\begin{tabular}{|c|c|c|c|c|}
\hline At most 5 & 41.21 & 0.0000 & 35.55 & 0.0001 \\
\hline At most 6 & 21.34 & 0.0189 & 21.34 & 0.0189 \\
\hline
\end{tabular}

*Probabilities are computed using asymptotic Chi-square distribution.

Source: EViews Software

In Table 5, the following pairwise variables yielded a statistically significant unidirectional causal relationship $(\rightarrow$ ) namely, running from $\mathrm{CO} 2$ to non-renewable energy consumption; CO2 per capita to real GDP per capita; real GDP per capita to nonrenewable energy consumption; real GDP per capita squared to non-renewable energy consumption; FDI to renewable energy consumption; and FDI to urbanization. On the other hand, the following pairwise variables yielded a statistically significant bidirectional causal relationship $(\leftrightarrow)$ namely, CO2 per capita and urbanization; real GDP per capita squared and $\mathrm{CO} 2$ per capita; FDI and non-renewable energy consumption; renewable and non-renewable energy consumption; urbanization and non-renewable energy consumption; urbanization and real GDP per capita; real GDP per capita squared and real GDP per capita; and lastly, real GDP per capita squared and urbanization. The remaining pairwise variables that did not yield a statistically significant causal relationship supported the neutrality hypothesis, wherein the null hypothesis of "no granger causality" is accepted at 5\% level of significance.

Table 5: Pairwise Granger Causality Tests

\begin{tabular}{|c|c|c|c|}
\hline Null Hypothesis: & Obs & F-Statist & Prob. \\
\hline $\begin{array}{l}\text { Non-renewable energy consumption does not Granger Cause CO2 } \\
\text { per capita }\end{array}$ & 321 & 0.90923 & 0.341 \\
\hline $\begin{array}{l}\text { CO2 per capita does not Granger Cause Non-r } \\
\text { consumption }\end{array}$ & & 7.83312 & 0.0054 \\
\hline FDI does not Granger Cause CO2 per capita & 589 & 0.21331 & 0.6444 \\
\hline CO2 per capita does not Granger Cause FDI & & 0.54412 & 0.461 \\
\hline $\begin{array}{l}\text { Renewable energy consumption does not Granger Cause CO2 per } \\
\text { capita }\end{array}$ & 154 & 1.2135 & 0.2724 \\
\hline $\begin{array}{l}\text { CO2 per capita does not Granger Cause Renewable energy } \\
\text { consumption }\end{array}$ & & 0.08606 & 0.7696 \\
\hline $\begin{array}{l}\text { Real GDP per capita does not Granger Cause CO2 per capita } \\
\text { CO2 per capita does not Granger Cause Real GDP per capita }\end{array}$ & 693 & $\begin{array}{l}0.92188 \\
26.4889\end{array}$ & $\begin{array}{l}0.3373 \\
3.00 \mathrm{E}-07\end{array}$ \\
\hline Urbanization does not Granger Cause $\mathrm{CO} 2$ per capita & 728 & 10.8133 & 0.0011 \\
\hline CO2 per capita does not Granger Cause Urbanization & & 8.8863 & 0.003 \\
\hline $\begin{array}{l}\text { Real GDP per capita (squared) does not Granger Cause CO2 per } \\
\text { capita }\end{array}$ & 693 & 5.39573 & 0.0205 \\
\hline $\begin{array}{l}\text { CO2 per capita does not Granger Cause Real GDP per capita } \\
\text { (squared) }\end{array}$ & & 18.7925 & $2.00 \mathrm{E}-05$ \\
\hline FDI does not Granger Cause Non-renewable energy consumption & 347 & 9.6583 & 0.002 \\
\hline Non-renewable energy consumption does not Granger Cause FDI & & 19.8839 & $1.00 \mathrm{E}-05$ \\
\hline $\begin{array}{l}\text { Renewable energy consumption does not Granger Cause Non- } \\
\text { renewable energy consumption } \\
\text { Non-renewable energy consumption does not Granger Cause }\end{array}$ & 172 & 45.7516 & $2.00 \mathrm{E}-10$ \\
\hline Renewable energy consumption & & 12.4379 & 0.0005 \\
\hline $\begin{array}{l}\text { Real GDP per capita does not Granger Cause Non-renewable energy } \\
\text { consumption }\end{array}$ & 347 & 13.7609 & 0.0002 \\
\hline $\begin{array}{l}\text { Non-renewable energy consumption does not Granger Cause Real } \\
\text { GDP }\end{array}$ & & 0.03044 & 0.8616 \\
\hline $\begin{array}{l}\text { Urbanization does not Granger Cause Non-renewable energy } \\
\text { consumption }\end{array}$ & 347 & 10.5802 & 0.0013 \\
\hline
\end{tabular}


Non-renewable energy consumption does not Granger Cause

Urbanization

72.1559

$6.00 \mathrm{E}-16$

Real GDP per capita (squared) does not Granger Cause Non-

renewable energy consumption

Non-renewable energy consumption does not Granger Cause Real GDP per capita (squared)

Renewable energy consumption does not Granger Cause FDI

FDI does not Granger Cause Renewable energy consumption

Real GDP per capita does not Granger Cause FDI

FDI does not Granger Cause Real GDP per capita

Urbanization does not Granger Cause FDI

FDI does not Granger Cause Urbanization

Real GDP per capita (squared) does not Granger Cause FDI

FDI does not Granger Cause Real GDP per capita (squared)

Real GDP per capita does not Granger Cause Renewable energy

consumption

Renewable energy consumption does not Granger Cause Real GDP

per capita

Urbanization does not Granger Cause Renewable energy

consumption

Renewable energy consumption does not Granger Cause

Urbanization

$\begin{array}{lll}347 & 11.4504 & 0.0008\end{array}$

$1.15643 \quad 0.283$

$182 \quad 1.55033 \quad 0.2147$

$20.4734 \quad 1.00 \mathrm{E}-05$

$\begin{array}{lll}614 & 0.60978 & 0.4352\end{array}$

$0.4592 \quad 0.4983$

$\begin{array}{lll}628 & 0.29881 & 0.5848\end{array}$

$23.9108 \quad 1.00 \mathrm{E}-06$

$\begin{array}{lll}614 & 1.251 & 0.2638\end{array}$

$0.0026 \quad 0.9593$

$182 \quad 0.7568 \quad 0.3855$

$0.82673 \quad 0.3644$

$182 \quad 0.11644 \quad 0.7333$

$57.0861 \quad 2.00 \mathrm{E}-12$

Real GDP per capita (squared) does not Granger Cause Renewable energy consumption

Renewable energy consumption does not Granger Cause Real GDP per capita (squared)

Urbanization does not Granger Cause Real GDP per capita

Real GDP per capita does not Granger Cause Urbanization

Real GDP per capita (squared) does not Granger Cause Real GDP per

capita

$\begin{array}{lll}182 & 0.78224 & 0.3776\end{array}$

$\begin{array}{lll}732 & 0.30778 & 0.5797 \\ 60.2404 & 3.00 \mathrm{E}-14\end{array}$

$41.2538 \quad 2.00 \mathrm{E}-10$

Real GDP per capita does not Granger Cause Real GDP per capita

(squared)

$44.2061 \quad 6.00 \mathrm{E}-11$

$24.329 \quad 1.00 \mathrm{E}-06$

\begin{tabular}{lll} 
Real GDP per capita (squared) does not Granger Cause Urbanization 732 & 31.9502 & $2.00 \mathrm{E}-08$ \\
Urbanization does not Granger Cause Real GDP per capita (squared) & 21.6453 & $4.00 \mathrm{E}-06$ \\
\hline
\end{tabular}

Source: EViews Software

To fully understand the causal relationship of the variables, the pairwise granger causality matrix in Table 6. was made with the grey boxes indicating rejection of the null hypothesis of "no granger causality" at 5\% level of significance. The unhighlighted boxes confirm the null hypothesis in support of the neutrality hypothesis, particularly in the energy-growth nexus.

Table 6: Pairwise Granger Causality Matrix

\begin{tabular}{llllllll}
\hline \multicolumn{1}{c}{$\mathbf{C O 2}$} & NEC & REC & FDI & GDP & GDP2 & URB \\
\hline CO2 & - & CO2 $\rightarrow$ NEC & CO2 $\rightarrow$ REC & CO2 $\rightarrow$ FDI & CO2 $\rightarrow$ GDP & CO2 $\leftrightarrow$ GDP2 & CO2 $\leftrightarrow$ URB \\
NEC & NEC $\rightarrow \mathrm{CO} 2$ & - & NEC $\leftrightarrow$ REC & NEC $\leftrightarrow$ FDI & NEC $\rightarrow$ GDP & NEC $\rightarrow$ GDP2 & NEC $\leftrightarrow$ URB \\
REC & REC $\rightarrow$ CO2 & REC $\leftrightarrow$ NEC & - & REC $\rightarrow$ FDI & REC $\rightarrow$ GDP & REC $\rightarrow$ GDP2 & REC $\rightarrow$ URB \\
FDI & FDI $\rightarrow \mathrm{CO} 2$ & FDI $\leftrightarrow$ NEC & FDI $\rightarrow$ REC & - & FDI $\rightarrow$ GDP & FDI $\rightarrow$ GDP2 & FDI $\rightarrow$ URB \\
GDP & GDP $\rightarrow$ CO2 2 & GDP $\rightarrow$ NEC & GDP $\rightarrow$ REC & GDP $\rightarrow$ FDI & - & GDP $\leftrightarrow$ GDP2 & GDP $\leftrightarrow$ URB \\
GDP2 & GDP2 $\leftrightarrow \mathrm{CO} 2$ & GDP2 $\rightarrow$ NEC & GDP2 $\rightarrow$ REC & GDP2 $\rightarrow$ FDI & GDP2 $\leftrightarrow$ GDP - & GDP2 $\leftrightarrow$ URB \\
URB & URB $\leftrightarrow \mathrm{CO} 2$ & URB $\leftrightarrow$ NEC & URB $\rightarrow$ REC & URB $\rightarrow$ FDI & URB $\leftrightarrow$ GDP & URB $\leftrightarrow$ GDP2 & - \\
\hline
\end{tabular}

Source: EViews Software 
In Table 7, the results of the panel unit root tests are at first difference of CO2 per capita, non-renewable energy, and renewable energy; it states that there is no unit root, or the series is stationary. It is also the same case with the second difference of the variable urbanization. The p-value is less than 0.05 , which indicates a rejection of the null hypothesis. On the other hand, the first difference of FDI and real GDP per capita shows that there is the presence of a unit root. Therefore, the results indicate rejection of the alternative hypothesis.

Table 7 Panel Unit Root Test Summary

\begin{tabular}{|c|c|c|c|c|c|}
\hline Series & Method & Statistic & Prob.** & Cross-sections & Obs \\
\hline $\mathrm{D}(\mathrm{CO} 2$ per capita & Levin, Lin \& Chu t* & -16.5392 & 0.0000 & 13 & 705 \\
\hline \multirow[t]{3}{*}{$(\mathrm{CO} 2))$} & Im, Pesaran and Shin W-stat & -17.4826 & 0.0000 & 13 & 705 \\
\hline & ADF - Fisher Chi-square & 313.156 & 0.0000 & 13 & 705 \\
\hline & PP - Fisher Chi-square & 397.363 & 0.0000 & 13 & 715 \\
\hline D(Non-renewable & Levin, Lin \& Chu t* & -5.23906 & 0.0000 & 13 & 315 \\
\hline Energy Consumption & Im, Pesaran and Shin W-stat & -9.16726 & 0.0000 & 13 & 315 \\
\hline \multirow[t]{2}{*}{$(\mathrm{NEC}))$} & ADF - Fisher Chi-square & 139.885 & 0.0000 & 13 & 315 \\
\hline & PP - Fisher Chi-square & 173.57 & 0.0000 & 13 & 333 \\
\hline D(Foreign Direct & Levin, Lin \& Chu $\mathrm{t}^{*}$ & 5.96818 & 1.0000 & 13 & 539 \\
\hline \multirow[t]{3}{*}{ Investments (FDI)) } & Im, Pesaran and Shin W-stat & -7.97009 & 0.0000 & 13 & 539 \\
\hline & ADF - Fisher Chi-square & 165.978 & 0.0000 & 13 & 539 \\
\hline & PP - Fisher Chi-square & 384.63 & 0.0000 & 13 & 615 \\
\hline D(Renewable energy & Levin, Lin \& Chu t* & -5.55066 & 0.0000 & 10 & 162 \\
\hline \multirow{3}{*}{ consumption (REC)) } & Im, Pesaran and Shin W-stat & -5.07965 & 0.0000 & 10 & 162 \\
\hline & ADF - Fisher Chi-square & 80.937 & 0.0000 & 10 & 162 \\
\hline & PP - Fisher Chi-square & 94.2192 & 0.0000 & 10 & 170 \\
\hline & Levin, Lin \& Chu t* & -0.81782 & 0.2067 & 13 & 691 \\
\hline \multirow{3}{*}{ (GDP)) } & Im, Pesaran and Shin W-stat & -4.62258 & 0.0000 & 13 & 691 \\
\hline & ADF - Fisher Chi-square & 140.153 & 0.0000 & 13 & 691 \\
\hline & PP - Fisher Chi-square & 210.246 & 0.0000 & 13 & 719 \\
\hline \multirow[t]{4}{*}{$\mathrm{D}$ (Urbanization (URB)) } & Levin, Lin \& Chu $\mathrm{t}^{*}$ & -21.1228 & 0.0000 & 12 & 673 \\
\hline & Im, Pesaran and Shin W-stat & -19.167 & 0.0000 & 12 & 673 \\
\hline & ADF - Fisher Chi-square & 330.778 & 0.0000 & 12 & 673 \\
\hline & PP - Fisher Chi-square & 347.258 & 0.0000 & 12 & 684 \\
\hline
\end{tabular}

*Levin, Lin \& Chu $t$ - Null: Unit root (assumes common unit root process) and Im, Pesaran and Shin $W$-stat, ADF - Fisher Chi-square, and PP - Fisher Chi-square - Null: Unit root (assumes individual unit root process)

**Probabilities for Fisher tests are computed using an asymptotic Chi-square distribution. All other tests assume asymptotic normality.

Source: EViews Software

To account for possible size distortions and disturbances in the panel data, the following cross-section dependence tests, specifically Breusch and Pagan LM test, Pesaran scaled LM test, and Pesaran CD test were utilized in validating the test statistics before proceeding with the panel data analysis as also employed in the studies of Hamit-Haggar (2012) and Arouri et al. (2012). Results in Table 8 illustrated that the null hypothesis of "no cross-section dependence (correlation)" is rejected for the Breusch and Pagan LM test and Pesaran scaled LM test while accepted for the Pesaran CD test at 1\% level of significance. With the panel data being cross-sectionally correlated, the researchers may proceed with the panel cross-section tests and estimation techniques. 
Table 8. Residual Cross-Section Dependence Test

\begin{tabular}{llll}
\hline Test & Statistic & d.f. & Prob. \\
\hline Breusch-Pagan LM & 112.1344 & 45 & 0.0000 \\
Pesaran scaled LM & 7.076589 & & 0.0000 \\
Pesaran CD & -0.352034 & & 0.7248 \\
\hline
\end{tabular}

Source: EViews Software

Results in Table 9 Panel Cross-section Heteroskedasticity LR Test (cross-section weights), which estimated a feasible panel GLS specification assuming the presence of cross-section heteroskedasticity, showed that all variables, except for FDI and Renewable energy consumption, were statistically significant. Non-renewable energy consumption (Coal, Diesel, Oil, and Natural Gas), FDI, and real GDP per capita positively impacts CO2 per capita while renewable energy consumption (Geothermal, Hydro, Solar, and Wind), urbanization, and real GDP per capita squared (quadratic terms) negatively impacts the CO2 per capita which are in conformity with the key assumptions and studies of Akram et al. (2020), Apergis and Payne (2009, 2010), Hossain (2011), Arouri et al. (2012), HamitHaggar (2012), Zakarya et al. (2015), and Wang et al. (2019).

Table 9: Panel Cross-section Heteroskedasticity LR Test and Panel EGLS

\begin{tabular}{lllll}
\hline Likelihood ratio & Value & df & Probability & \\
\hline LR test summary: & $\mathbf{3 5 3 . 2 3 8 2}$ & $\mathbf{1 0}$ & $\mathbf{0 . 0 0 0 0}$ & \\
Restricted LogL & Value & $\mathbf{d f}$ & & \\
Unrestricted LogL & -361.0703 & 158 & & \\
Variable & -184.4512 & 158 & t-Statistic & Prob. \\
\hline Constant & Coefficient & Std. Error & 12.82657 & 0.0000 \\
Non-renewable energy (NEC) & 1.544194 & 0.12039 & 3.381315 & 0.0009 \\
Foreign Direct Investments & $2.00 \mathrm{E}-14$ & $5.92 \mathrm{E}-15$ & & \\
(FDI) & & & 1.028016 & 0.3055 \\
Renewable energy (REC) & $1.36 \mathrm{E}-12$ & $1.32 \mathrm{E}-12$ & -0.835567 & 0.4047 \\
real GDP per capita (GDP) & $-6.59 \mathrm{E}-14$ & $7.89 \mathrm{E}-14$ & 46.69841 & 0.0000 \\
Urbanization (URB) & 0.000995 & $2.13 \mathrm{E}-05$ & -13.55881 & 0.0000 \\
Quadratic term of GDP (GDP2) & -0.058038 & 0.00428 & -38.15246 & 0.0000 \\
Weighted Statistics & $-1.61 \mathrm{E}-08$ & $4.23 \mathrm{E}-10$ & & \\
\hline Root MSE & & & & 0.985531 \\
Mean dependent var & 4.091347 & R-squared & & 0.984981 \\
S.D. dependent var & 43.47538 & Adjusted R-squared & & 2760996 \\
Akaike info criterion & 43.8409 & S.E. of regression & & -184.4512 \\
Schwarz criterion & 2.32062 & Sum squared resid & & 1793.64 \\
Hannan-Quinn criter. & 2.452387 & Log likelihood & & 0.000000 \\
Durbin-Watson stat & 2.374109 & F-statistic & & \\
Unweighted Statistics & 0.35182 & Prob(F-statistic) & & 6.900486 \\
\hline R-squared & & & & 0.009056 \\
\hline Sum squared resid & 0.411056 & Mean dependent var & &
\end{tabular}

Source: EViews Software

Results in Table 10 Panel Period Heteroskedasticity LR Test (period weights), which estimated a feasible panel GLS specification with the absence of period heteroskedasticity, showed that all variables except for Non-renewable energy consumption and urbanization were statistically significant bearing the same effects to the results yielded from the panel cross-section test. 
Table 10: Panel Period Heteroskedasticity LR Test and Panel EGLS

\begin{tabular}{|c|c|c|c|c|}
\hline Likelihood ratio & $\begin{array}{l}\text { Value } \\
10.97139 \\
\end{array}$ & $\begin{array}{l}\text { df } \\
10\end{array}$ & $\begin{array}{l}\text { Probability } \\
0.3598\end{array}$ & \\
\hline LR test summary: & Value & df & & \\
\hline Restricted LogL & -361.0703 & 158 & & \\
\hline Unrestricted LogL & -355.5846 & 158 & & \\
\hline Variable & Coefficient & Std. Error & t-Statistic & Prob. \\
\hline Constant & 1.266151 & 1.05587 & 1.199154 & 0.2323 \\
\hline Non-renewable energy (NEC) & $1.44 \mathrm{E}-14$ & $2.17 \mathrm{E}-14$ & 0.664934 & 0.5071 \\
\hline \multicolumn{5}{|l|}{ Foreign Direct Investments } \\
\hline Renewable energy (REC) & $-1.27 \mathrm{E}-12$ & $2.73 \mathrm{E}-13$ & -4.642 & 0.0000 \\
\hline real GDP per capita (GDP) & 0.000422 & 0.000105 & 4.039114 & 0.0001 \\
\hline Urbanization (URB) & -0.005405 & 0.0314 & -0.172132 & 0.8636 \\
\hline Quadratic term of GDP (GDP2) & $-3.64 \mathrm{E}-09$ & $1.52 \mathrm{E}-09$ & -2.39637 & 0.0177 \\
\hline \multicolumn{5}{|c|}{ Weighted Statistics } \\
\hline Root MSE & 2.194735 & R-squared & & 0.857392 \\
\hline Mean dependent var & 7.34963 & Adjusted R-squared & & 0.851976 \\
\hline S.D. dependent var & 5.934358 & S.E. of regression & & 2.242826 \\
\hline Akaike info criterion & 4.394964 & Sum squared resid & & 794.7823 \\
\hline Schwarz criterion & 4.526732 & Log likelihood & & -355.5846 \\
\hline Hannan-Quinn criter. & 4.448453 & F-statistic & & 158.3218 \\
\hline Durbin-Watson stat & 0.209577 & Prob(F-statistic) & & 0.000000 \\
\hline \multicolumn{5}{|l|}{ Unweighted Statistics } \\
\hline R-squared & 0.830523 & Mean dependent var & & 6.900486 \\
\hline Sum squared resid & 794.8039 & Durbin-Watson stat & & 0.230915 \\
\hline
\end{tabular}

Source: EViews Software

Results yielded from all panel regression outputs and cointegration test managed to be somewhat statistically significant in conformity with the key assumptions from the researchers' related literature. In terms of the pairwise granger causality test, only a few relevant causal relationships proved and disproved the direction of causality for the following: nexus between energy consumption and CO2 emissions, nexus between energy consumption and economic growth, and the pollution-haven and -halo hypothesis. First, there exists a unidirectional causal relationship running from real GDP per capita to Nonrenewable energy consumption (GDP $\rightarrow$ NEC), which supports the conservation hypothesis thus implying that energy conservation policies would not adversely impact economic growth. However, there also exists an insignificant causal relationship for real GDP per capita and Renewable energy consumption (GDP \& REC) which supports the neutrality hypothesis thus implying that neither growth nor energy conservation policies would not adversely affect economic growth. Second, there exists a unidirectional causal relationship running from FDI to Renewable energy consumption (FDI $\rightarrow$ REC) and urbanization (FDI $\rightarrow \mathrm{URB}$ ) which implies that FDI drives both of the latter, thus, an increase in FDI would granger cause an increase for renewable energy consumption and improvement in urbanization at some level.

While all panel regressions (panel least squares and panel EGLS) resulted in statistically significant figures for some variables, it is best to note that with such a large number of observations, cross-section dependence test must be utilized in order to account for possible size distortions, errors, and disturbances in the model, especially assuming the presence and absence of heteroskedasticity in the panel regression outputs. In comparing the panel least squares, panel cross-section, and panel period regressions, the latter is the 
best and closest reference for the researchers' inference as it already illustrated the absence of heteroskedasticity as well as having the entire model statistically significant as supported by the F-statistic at 1\% level of significance. However, it is also noteworthy that differences with the panel least squares and the panel EGLS can be seen, particularly with the Quadratic terms of real GDP per capita (or real GDP per capita squared) being statistically significant but with different impacts to $\mathrm{CO} 2$ per capita as this pertinent variable is crucial for the researchers to determine whether the EKC and E-EKC hypothesis exists for the aggregated model. In analyzing both regression outputs, for the panel least squares, real GDP per capita squared positively affects $\mathrm{CO} 2$ per capita which disproves the EKC and E-EKC hypothesis in the specified model for selected countries in the APAC region as the key assumption suggests that real GDP per capita squared should negatively affect $\mathrm{CO} 2$ per capita illustrating the inverted U-shaped curve of the said hypotheses. On the other hand, the panel EGLS regression showed otherwise and proved the existence of the EKC and E-EKC hypothesis with real GDP per capita squared negatively affecting $\mathrm{CO} 2$ per capita. Such contrasting results in the panel regression outputs are caused by utilizing the cross-section dependence test in the panel data which has corrected some of the discrepancies in the model, thus making the results for the panel EGLS more robust than the mere panel least squares regression.

\section{Conclusion and Recommendation}

The main objective of this research is to determine whether there exists a short- and longrun relationship between the independent variables (non-renewable and renewable energy consumption, FDI, real GDP per capita and GDP per capita squared, and urbanization) and dependent variable (CO2 per capita) in thirteen (13) countries in the Asia Pacific region from 1960-2019, proving or disproving the Environmental Kuznets Curve (EKC) hypothesis, Energy-Environmental Kuznets Curve (E-EKC) hypothesis, pollution-haven and -halo hypothesis in this study as well as to examine pertinent causal relationships among the variables. The researchers also aim to provide effective recommendations to policymakers for carbon emission reduction and different strategies that can enhance energy efficiency for a sustainable economy to cultivate, as inferred from the results of the study.

Summarizing the findings from the tests that the researchers conducted, this paper proved the existence of Environmental Kuznets Curve (EKC) which are consistent with the findings of Apergis and Payne (2010), Saboori, Sulaiman, and Mohd (2012), Al-Mulali and Ozturk (2015), Ummalla and Goyari (2021) and also corroborate the subsistence of Energy-Environmental Kuznets Curve (E-EKC) for thirteen (13) selected countries in the Asia Pacific region using panel EGLS and cointegration test. The researchers concluded that the impact of the independent variables to $\mathrm{CO} 2$ per capita are consistent with the results of most studies mentioned in the key assumptions, particularly with nonrenewable energy consumption, FDI, and real GDP per capita positively affecting CO2 emissions while renewable energy consumption, urbanization, and real GDP per capita squared (quadratic terms) negatively affects $\mathrm{CO} 2$ emissions. Pollution haven hypothesis was also identified in accordance with the acquired results. This means that FDI would drive $\mathrm{CO} 2$ emissions to further increase as pollution-intensive industries penetrate those countries with less stringent environmental policies. Furthermore, results from the pairwise granger causality test supported the conservation and neutrality hypothesis among the selected countries wherein the former showed a unidirectional causal relationship running from real GDP per capita to non-renewable energy consumption 
(GDP $\rightarrow$ NEC) thus, implying that energy conservation policies will not adversely affect economic growth.

For further research, the proponents suggest that future researchers investigate adding or omitting independent variables in the study to focus more on pertinent hypothesis related to the energy-growth-environment nexus and make use of data from other countries and specific regions such as selected emerging countries, ASEAN, BRICS, and MENA for a more streamlined cross-sectional analysis in order to gain more insights on a micro and macro level. The proponents also suggest that future researchers make use of varying methods such as utilizing non-parametric, DSUR, GMM, and other panel regression tests as well as a panel country regression analysis to reduce errors in the model as well as to compare countries that have varying response to the energy-growthenvironment nexus hypothesis for a more specific policy recommendation. In addition, they may also make use of varying dependent variables aside from $\mathrm{CO} 2 \mathrm{Emissions} \mathrm{such} \mathrm{as}$ greenhouse gas emissions, particulate matter, and nitrous oxide emissions among others that largely contribute to environmental degradation. Future researchers may also include dummy variables such as, but not limited to, the presence or absence of energy and environmental laws and policies (i.e., energy conservation policies and renewable energy policies), development plans, and government projects implemented in their respective countries.

\section{Policy Implications}

This study sought to contribute to the development of the Environmental Kuznets Curve (EKC) and Energy-Environmental Kuznets Curve (E-EKC) in which the researchers reiterated that there is an existence of EKC and E-EKC in selected Asia Pacific countries. One of the problems that the researchers encountered in the entire duration of the study is that there are limited studies that were conducted to prove or disprove both the existence of EKC and E-EKC in the Asia Pacific region.

Since it was found that the variables (Non-renewable energy consumption and FDI) increase $\mathrm{CO} 2$ emissions and that such countries conform to the conservation hypothesis, policy makers must also take into consideration opting for adding renewable and clean energy (such as hydro, solar, geothermal, and wind) in their respective energy mix to not only curtail $\mathrm{CO} 2$ emissions without hampering growth but also ultimately for pursuing sustainability in the long run. In addition, Asia Pacific countries can also adapt the 'Asia Pacific Low Carbon Lifestyles Challenge' wherein the people can pitch valuable solutions or policies that can be beneficial to the goal of building a sustainable economy and a healthy environment. This program spearheaded by the United Nations (UN) enriches the creativity of people in finding solutions to one of the world's biggest problems and showcases different implementation strategies to make sure that it will have a positive impact on the environment as well as on the economy.

The existence of the pollution-haven hypothesis can also be a cautionary message to those countries included in this research paper to further enhance their trade policies and produce more stringent economic-environmental policies to strengthen their strategies to achieve a sustainable economy fuelled by a feasible mix of non-renewable and renewable energy and at the same time aid in mitigating climate change, particularly in curtailing $\mathrm{CO} 2$ emissions. Moreover, those countries should make sure that environmental and trade policies will be strictly implemented and monitored properly to accurately measure the effectiveness of such policies and its effect to $\mathrm{CO} 2$ emission levels. 
Lastly, a market-based approach, through utilizing environmental taxes and tradable permits, can also be applied wherein producers and consumers in Asia Pacific countries will receive economic incentives as they intensify innovative practices and efficiently use resources (i.e., harnessing clean and renewable energy sources). It is also more costeffective and elastic than solely implementing stringent traditional environmental policies. Such an approach can be a tool for effective and efficient economic growth and at the same time improve environmental conditions if it is well implemented and strictly enforced. However, successful implementation of the market-based approach requires long-term commitment by the government and will take years for such levels of carbon emissions to be accomplished. While such an approach is feasible, one must also take cautionary steps as industries subjected to such taxes and additional permits could easily exploit the scheme that would inadvertently even raise more problems in the everincreasing carbon emission levels if left unmonitored and unmanaged.

\section{Acknowledgement}

This research would not have been possible if it were not for the unfaltering and steadfast support of our professors, mentors, family, and friends. First, we would like to express our utmost and heartfelt gratitude to Assoc. Prof. Ronaldo R. Cabauatan, PhD (our research adviser) and Asst. Prof. Marie Antoinette L. Rosete, PhD (Research 1 and 2 faculty adviser) for patiently guiding us through the webs of writing our very first thesis (and hopefully not the last) on the topic of energy economics. We would also like to extend our deepest appreciation to both of our parents for their unwavering support, encouragement, and most especially, for creating a peaceful working environment for us to produce quality work in.

\section{Funding}

This study received no funding.

\section{Conflict of Interests}

The authors declare no conflict of interest in this study.

\section{References}

Abdollahi, H. (2020). Investigating Energy Use, Environment Pollution, and Economic Growth in Developing Countries. Environmental and Climate Technologies, 24(1), 275-293. https://doi.org/10.2478/rtuect-2020-0016

Adeel-Farooq, R., Riaz, M., \& Ali, T. (2021). Improving the environment begins at home: Revisiting the links between FDI and environment. Energy, 215, 119150. https://doi.org/10.1016/j.energy.2020.119150

Ahmad, N., Du, L., Lu, J., Wang, J., Li, H., \& Hashmi, M. Z. (2017). Modelling the CO2 emissions and economic growth in Croatia: Is there any environmental Kuznets curve? Energy, 123, 164-172. https://doi.org/10.1016/j.energy.2016.12.106

Akram, R., Chen, F., Khalid, F., Ye, Z., \& Majeed, M. T. (2020). Heterogeneous effects of energy efficiency and renewable energy on carbon emissions: Evidence from 
developing countries. Journal of Cleaner Production, 247, 119122. https://doi.org/10.1016/j.jclepro.2019.119122

Alam, J. (2014). On the relationship between economic growth and CO2 emissions: The Bangladesh experience. IOSR Journal of Economics and Finance (IOSR-JEF), 5(6), 3641. https://www.iosrjournals.org/iosr-jef/papers/Vol5-Issue6/Version1/G05613641.pdf

Alam, M., Begum, I., Buysse, J., Rahman, S., \& Van Huylenbroeck, G. (2011). Dynamic modeling of causal relationship between energy consumption, $\mathrm{CO} 2$ emissions and economic growth in India. Renewable and Sustainable Energy Reviews, 15(6), 32433251. https://doi.org/10.1016/j.rser.2011.04.029

Al-Mulali, U. \& Ozturk, I. (2015). The effect of energy consumption, urbanization, trade openness, industrial output, and the political stability on the environmental degradation in the MENA (Middle East and North African) region. Energy, 84, 382389. https://doi.org/10.1016/j.energy.2015.03.004

Antonakakis, N., Chatziantoniou, I., \& Filis, G. (2017). Energy consumption, CO2 emissions, and economic growth: An ethical dilemma. Renewable and Sustainable Energy Reviews, 68, 808-824. https://doi.org/10.1016/j.rser.2016.09.105

Apergis, N., \& Payne, J. (2009). Energy consumption and economic growth in Central America: Evidence from a panel cointegration and error correction model. Energy Economics, 31(2), 211-216. https://doi.org/10.1016/j.eneco.2008.09.002

Apergis, N., \& Payne, J. (2010). The emissions, energy consumption, and growth nexus: Evidence from the commonwealth of independent states. Energy Policy, 38(1), 650655. https://doi.org/10.1016/j.enpol.2009.08.029

Arouri, M., Youssef, A., M'henni, H., \& Rault, C. (2012). Energy consumption, economic growth and $\mathrm{CO} 2$ emissions in Middle East and North African countries. Energy Policy, 45, 342-349. https://doi.org/10.1016/j.enpol.2012.02.042

Aruga, K. (2019). Investigating the energy-environmental Kuznets Curve hypothesis for the Asia-Pacific region. Sustainability, 11(8), 2395. https://doi.org/10.3390/su11082395

Baek, J. (2015). A panel cointegration analysis of CO2 emissions, nuclear energy and income in major nuclear generating countries. Applied Energy, 145, 133-138. https://doi.org/10.1016/j.apenergy.2015.01.074

Bilgili, F., Koçak, E., \& Bulut, Ü. (2016). The dynamic impact of renewable energy consumption on CO 2 emissions: A revisited Environmental Kuznets Curve approach. Renewable and Sustainable Energy Reviews, 54, 838-845. https://doi.org/10.1016/j.rser.2015.10.080

Bozoklu, S., \& Yilanci, V. (2013). Energy consumption and economic growth for selected OECDa countries: Further evidence from the Granger causality test in the frequency domain. Energy Policy, 63, 877-881. https://doi.org/10.1016/j.enpol.2013.09.037

BP Statistical Review of World Energy 2020. (2020a). Primary energy. In Statistical Review of World Energy 2020 (69th ed., pp. 10-13). BP Statistical Review of World Energy. https://www.bp.com/content/dam/bp/business-

sites/en/global/corporate/pdfs/energy-economics/statistical-review/bp-statsreview-2020-full-report.pdf

BP Statistical Review of World Energy 2020. (2020b). Statistical Review of World Energy - all data, 1965-2020. BP Statistical Review of World Energy. https://www.bp.com/en/global/corporate/energy-economics/statistical-reviewof-world-energy/downloads.html

$\mathrm{Bu}, \mathrm{M} .$, \& Wagner, M. (2016). Racing to the bottom and racing to the top: The crucial role of firm characteristics in foreign direct investment choices. Journal of International Business Studies, 47(9), 1032-1057. https://doi.org/10.1057/s41267-016-0013-4 
Cabauatan, R., \& Tatlonghari, V. M. (2017). Analysing energy consumption in the Philippines using vector error correction. International Social Science Journal, 67(225-226), 137-150. https://doi.org/10.1111/issj.12136

Chen, Y., Zhao, J., Lai, Z., Wang, Z., \& Xia, H. (2019). Exploring the effects of economic growth, and renewable and non-renewable energy consumption on China's CO2 emissions: Evidence from a regional panel analysis. Renewable Energy, 140, 341353. https://doi.org/10.1016/j.renene.2019.03.058

Chng, Z. Y. R. (2019). Environmental Degradation and Economics Growth: Testing the Environmental Kuznets Curve Hypothesis (EKC) in Six ASEAN Countries. Journal of Undergraduate Research at Minnesota State University, Mankato, 19(1), 1. https://cornerstone.lib.mnsu.edu/jur/vol19/iss1/1

Chowdhury, R., \& Moran, E. (2012). Turning the curve: A critical review of Kuznets approaches. Applied Geography, 32(1), 3-11. https://doi.org/10.1016/j.apgeog.2010.07.004

Cole, M. A. (2004). Trade, the pollution haven hypothesis and the environmental Kuznets curve: Examining the linkages. Ecological Economics, 48(1), 71-81. https://doi.org/10.1016/j.ecolecon.2003.09.007

Copeland, B. R., \& Taylor, M. S. (1994). North-South Trade and the Environment. The Quarterly Journal of Economics, 109(3), 755-787. https://doi.org/10.2307/2118421

Dogan, E., \& Aslan, A. (2017). Exploring the relationship among CO2 emissions, real GDP, energy consumption and tourism in the EU and candidate countries: Evidence from panel models robust to heterogeneity and cross-sectional dependence. Renewable $\begin{array}{llll}\text { and Sustainable Energy 239-245. } & \text { Reviews, 77, }\end{array}$ https://doi.org/10.1016/j.rser.2017.03.111

Essandoh, O., Islam, M., \& Kakinaka, M. (2020). Linking international trade and foreign direct investment to $\mathrm{CO} 2$ emissions: Any differences between developed and developing countries?. Science of the Total Environment, 712, 136437. https://doi.org/10.1016/j.scitotenv.2019.136437

Hamit-Haggar, M. (2012). Greenhouse gas emissions, energy consumption and economic growth: A panel cointegration analysis from Canadian industrial sector perspective. Energy Economics, 34(1), 358-364. https://doi.org/10.1016/j.eneco.2011.06.005

Hao, Y., \& Liu, Y. M. (2015). Has the development of FDI and foreign trade contributed to China's CO 2 emissions? An empirical study with provincial panel data. Natural Hazards, 76(2), 1079-1091. https://doi.org/10.1007/s11069-014-1534-4

Hossain, M. (2011). Panel estimation for CO2 emissions, energy consumption, economic growth, trade openness and urbanization of newly industrialized countries. Energy Policy, 39(11), 6991-6999. https://doi.org/10.1016/j.enpol.2011.07.042

Hsiao, C., Li, Q., \& Racine, J. (2007). A consistent model specification test with mixed discrete and continuous data. Journal of Econometrics, 140(2), 802-826. https://doi.org/10.1016/j.jeconom.2006.07.015

International Energy Agency (2019), World Energy Outlook 2019, IEA, Paris. https://www.iea.org/reports/world-energy-outlook-2019

International Monetary Fund. (2018, April). Regional economic outlook. Asia Pacific: Good times, uncertain times, a time to prepare. (No. 978-14-8433-988-6). https://www.imf.org/-/media/Files/Publications/REO/APD/2018/apd-reo-fullreport.ashx

International Renewable Energy Agency. (2020, June). Renewable Power Generation Costs in 2019 (No.978-92-9260-244-4). https://www.irena.org//media/Files/IRENA/Agency/Publication/2020/Jun/ IRENA_Power_Generation_Costs_2019.pdf 
Iwata, H., Okada, K., \& Samreth, S. (2012). Empirical study on the determinants of CO2 emissions: Evidence from OECD countries. Applied Economics, 44(27), 3513-3519. https://doi.org/10.1080/00036846.2011.57702

Joo, Y., Kim, C., \& Yoo, S. (2015). Energy consumption, CO2 emission, and economic growth: evidence from Chile. International Journal of Green Energy, 12(5), 543-550. https://doi.org/10.1080/15435075.2013.834822

Kahia, M., Omri, A., \& Jarraya, B. (2021). Green Energy, Economic Growth and Environmental Quality Nexus in Saudi Arabia. Sustainability, 13(3), 1264. https://doi.org/10.3390/su13031264

Kheder, S. B., \& Zugravu, N. (2008). The Pollution Haven Hypothesis: A Geographic Economy Model in a Comparative Study. SSRN Electronic Journal. https://doi.org/10.2139/ssrn.1266705

Kozul-Wright, R., \& Fortunato, P. (2012). International trade and carbon emissions. The European Journal of Development Research, 24(4), 509-529. https://doi.org/10.1057/ejdr.2012.15

Kraft, J., \& Kraft, A. (1978). On the Relationship Between Energy and GNP. The Journal of Energy and Development, 3(2), 401-403. Retrieved April 24, 2021, from http://www.jstor.org/stable/24806805

Kuznets, S. (1956). Quantitative Aspects of the Economic Growth of Nations: I. Levels and Variability of Rates of Growth. Economic Development and Cultural Change, 5(1), 1 94. https://doi.org/10.1086/449724

Liddle, B. (2013). Impact of population, age structure, and urbanization on carbon emissions/energy consumption: Evidence from macro-level, cross-country analyses. Population and Environment, 35(3), 286-304. https://doi.org/10.1007/s11111-013-0198-4

Lütkepohl, H. (1982). Non-causality due to omitted variables. Journal of Econometrics, 19(2-3), 367-378. https://doi.org/10.1016/0304-4076(82)90011-2

Magazzino, C. (2016a). CO2 emissions, economic growth, and energy use in the Middle East countries: A panel VAR approach. Energy Sources, Part B: Economics, Planning, and Policy, 11(10), 960-968. https://doi.org/10.1080/15567249.2014.940092

Magazzino, C. (2016b). The relationship between CO2 emissions, energy consumption and economic growth in Italy. International Journal of Sustainable Energy, 35(9), 844857. https://doi.org/10.1080/14786451.2014.953160

Mbarek, M., Saidi, K., \& Rahman, M. (2017). Renewable and non-renewable energy consumption, environmental degradation and economic growth in Tunisia. Quality \& Quantity, 52(3), 1105-1119. https://doi.org/10.1007/s11135-017-0506-7

Mert, M., \& Caglar, A. E. (2020). Testing pollution haven and pollution halo hypotheses for Turkey: A new perspective. Environmental Science and Pollution Research, 27(26), 32933-32943. https://doi.org/10.1007/s11356-020-09469-7

Mirza, F. M., \& Kanwal, A. (2017). Energy consumption, carbon emissions and economic growth in Pakistan: Dynamic causality analysis. Renewable and Sustainable Energy Reviews, 72, 1233-1240. https://doi.org/10.1016/j.rser.2016.10.081

Munir, Q., Lean, H., \& Smyth, R. (2020). CO2 emissions, energy consumption and economic growth in the ASEAN-5 countries: A cross-sectional dependence approach. Energy Economics, 85, 104571. https://doi.org/10.1016/j.eneco.2019.104571

Naz, S., Sultan, R., Zaman, K., Aldakhil, A. M., Nassani, A. A., \& Abro, M. M. (2018). Moderating and mediating role of renewable energy consumption, FDI inflows, and economic growth on carbon dioxide emissions: Evidence from robust least square estimator. Environmental Science and Pollution Research, 26(3), 2806-2819. https://doi.org/10.1007/s11356-018-3837-6 
Neumayer, E. (2001). Pollution Havens: An Analysis of Policy Options for Dealing with an Elusive Phenomenon. The Journal of Environment \& Development, 10(2), 147-177. https://doi.org/10.1177/107049650101000203

Ozcan, B., \& Ozturk, I. (2019). Renewable energy consumption-economic growth nexus in emerging countries: A bootstrap panel causality test. Renewable and Sustainable Energy Reviews, 104, 30-37. https://doi.org/10.1016/j.rser.2019.01.020

Ozturk, I., \& Acaravci, A. (2010). CO2 emissions, energy consumption and economic growth in Turkey. Renewable and Sustainable Energy Reviews, 14(9), 3220-3225. https://doi.org/10.1016/j.rser.2010.07.005

Ozturk, I., \& Salah Uddin, G. (2012). Causality among carbon emissions, energy consumption and growth in India. Economic research-Ekonomska istraživanja, 25(3), 752-775. https://doi.org/10.1080/1331677X.2012.11517532

Ozturk, I., Aslan, A., \& Kalyoncu, H. (2010). Energy consumption and economic growth relationship: Evidence from panel data for low and middle income countries. Energy Policy, 38(8), 4422-4428. https://doi.org/10.1016/j.enpol.2010.03.071

Öztürk, Z., \& Öz, D. (2016). The relationship between energy consumption, income, foreign direct investment, and $\mathrm{CO} 2$ emissions: the case of Turkey. Cankırı Karatekin $\begin{array}{llll}\text { Üniversitesi } \quad \text { IIBF } & \text { Dergisi, 269-288. }\end{array}$ https://dergipark.org.tr/tr/download/article-file/382471

Pablo-Romero, M. del P., \& Sánchez-Braza, A. (2017). Residential energy environmental Kuznets curve in the EU-28. Energy, 125, 44-54. https://doi.org/10.1016/j.energy.2017.02.091

Pata, U. K. (2017). The effect of urbanization and industrialization on carbon emissions in Turkey: Evidence from ARDL bounds testing procedure. Environmental Science and Pollution Research, 25(8), 7740-7747.https://doi.org/10.1007/s11356-017-1088-6

Rahman, M., \& Majumder, S. (2020). Nexus between energy consumptions and CO2 emissions in selected industrialized countries. International Journal of Entrepreneurial Research,3(1), 13-19. https://doi.org/10.31580/ijer.v3i1.1174

Rahman, Z., Cai, H., \& Ahmad, M. (2019). A new look at the remittances-FDI-energyenvironment nexus in the case of selected Asian nations. The Singapore Economic Review, 1-19. https://doi.org/10.1142/S0217590819500176

Regional Project Energy Security and Climate Change in Asia and Pacific KonradAdenauer-Stiftung. (2017). Asia's Climate Change and Energy Security in Figures. Konrad-Adenauer-Stiftung, Hong Kong SAR. https://www.kas.de/c/document_library/get_file?uuid=231bb46d-04dd-54f4df56-0e4a63891efa\&groupId=252038a

REN 21 \& Economic and Social Commission for Asia and the Pacific (ESCAP). (2019). Asia and the Pacific Renewable Energy Status Report (ISBN 978-3-9818911-8-8). REN21 Secretariat, Asian Development Bank, Paris. https://www.adb.org/sites/default/files/publication/611911/asia-pacificrenewable-energy-status.pdf

Repkine, A., \& Min, D. (2020). Foreign-Funded Enterprises and Pollution Halo Hypothesis: A Spatial Econometric Analysis of Thirty Chinese Regions. Sustainability, 12(12), 5048. https://doi.org/10.3390/su12125048

Saboori, B., Sulaiman, J., \& Mohd, S. (2012). Economic growth and CO2 emissions in Malaysia: a cointegration analysis of the environmental Kuznets curve. Energy policy, 51, 184-191. https://doi.org/10.1016/j.enpol.2012.08.065

Sarkodie, S., \& Ozturk, I. (2020). Investigating the Environmental Kuznets Curve hypothesis in Kenya: A multivariate analysis. Renewable and Sustainable Energy Reviews, 117, 109481. https://doi.org/10.1016/j.rser.2019.109481 
Sebri, M., \& Ben-Salha, O. (2014). On the causal dynamics between economic growth, renewable energy consumption, $\mathrm{CO} 2$ emissions and trade openness: Fresh evidence from BRICS countries. Renewable and Sustainable Energy Reviews, 39, 14-23. https://doi.org/10.1016/j.rser.2014.07.033

Shahbaz, M., Balsalobre-Lorente, D., \& Sinha, A. (2019). Foreign direct Investment-CO2 emissions nexus in Middle East and North African countries: Importance of biomass energy consumption. Journal of Cleaner Production, 217, 603-614. https://doi.org/10.1016/j.jclepro.2019.01.282

Shahbaz, M., Khan, S., \& Tahir, M. I. (2013). The dynamic links between energy consumption, economic growth, financial development and trade in China: Fresh evidence from multivariate framework analysis. Energy Economics, 40, 8-21. https://doi.org/10.1016/j.eneco.2013.06.006

Shahbaz, M., Lean, H. H., \& Shabbir, M. S. (2012). Environmental Kuznets Curve hypothesis in Pakistan: Cointegration and Granger causality. Renewable and Sustainable Energy Reviews, 16(5), 2947-2953. https://doi.org/10.1016/j.rser.2012.02.015

Shahbaz, M., Loganathan, N., Zeshan, M., \& Zaman, K. (2015). Does renewable energy consumption add in economic growth? An application of auto-regressive distributed lag model in Pakistan. Renewable and Sustainable Energy Reviews, 44, 576-585. https://doi.org/10.1016/j.rser.2015.01.017

Shahbaz, M., Shafiullah, M., Papavassiliou, V. G., \& Hammoudeh, S. (2017). The CO 2 growth nexus revisited: A nonparametric analysis for the G7 economies over nearly two centuries. Energy Economics, 65, 183-193. https://doi.org/10.1016/j.eneco.2017.05.007

Sharma, S. S. (2011). Determinants of carbon dioxide emissions: Empirical evidence from 69 countries. Applied Energy, 88(1), 376-382. https://doi.org/10.1016/j.apenergy.2010.07.022

Sinaga, O., Alaeddin, O., \& Jabarullah, N. H. (2019). The impact of hydropower energy on the environmental Kuznets curve in Malaysia. International Journal of Energy Economics and Policy, 9(1), 308-315. https://ideas.repec.org/a/eco/journ2/201901-39.html

Sulaiman, C. (2014). The causality between energy consumption, CO2 emissions and economic growth in Nigeria: An application of Toda and Yamamoto Procedure. Advances in Natural and Applied Sciences, 8(8), 75-82. https://go.gale.com/ps/i.do?p=AONE\&u=anon f090ffa\&id=GALE|A384543834\&v $=2.1 \& i t=r \&$ sid $=$ googleScholar\&asid $=$ fad 3 fae 0

The World Bank. (1960-2016). CO2 emissions (metric tons per capita) - East Asia \& Pacific | Data [Dataset]. https://data.worldbank.org/indicator/EN.ATM.CO2E.PC

The World Bank. (1960-2019a). GDP (constant 2010 US\$) - East Asia \& Pacific | Data [Dataset]. https://data.worldbank.org/indicator/NY.GDP.MKTP.KD?locations=Z4

The World Bank. (1960-2019b). Urban population (\% of total population) - East Asia \& Pacific | Data [Dataset]. https://data.worldbank.org/indicator/SP.URB.TOTL.IN.ZS?locations=Z4

The World Bank. (1970-2019). Foreign direct investment, net inflows (BoP, current US\$) - East Asia \& Pacific | Data [Dataset]. https://data.worldbank.org/indicator/BX.KLT.DINV.CD.WD?locations=Z4

Ummalla, M., \& Goyari, P. (2021). The impact of clean energy consumption on economic growth and CO2 emissions in BRICS countries: Does the environmental Kuznets curve exist?. Journal of Public Affairs, 21(1), e2126. https://doi.org/10.1002/pa.2126

United Nations Development Programme. (2020, March). A Review of Multidimensional Poverty Index and Uses in Asia-Pacific. (No. 978-974-680-432-5). 
https://www.undp.org/publications/review-multidimensional-poverty-indexand-uses-asia-pacific

United Nations. (2015, September). Transforming our world: The 2030 Agenda for Sustainable Development.

https://sustainabledevelopment.un.org/post2015/transformingourworld/publica tion

Wang, Z., Rasool, Y., Zhang, B., Ahmed, Z., \& Wang, B. (2019). Dynamic linkage among industrialisation, urbanisation, and $\mathrm{CO} 2$ emissions in APEC realms: evidence based on DSUR estimation. Structural Change and Economic Dynamics. https://doi.org/10.1016/j.strueco.2019.12.001

Wasti, S., \& Zaidi, S. (2020). An empirical investigation between CO2 emission, energy consumption, trade liberalization and economic growth: A case of Kuwait. Journal of Building Engineering, 28, 101104. https://doi.org/10.1016/j.jobe.2019.101104

Xia, C., \& Wang, Z. (2020). The Effect Of Fossil Fuel And Hydropower On Carbon Dioxide Emissions: Ekc Validation With Structural Breaks. Journal of Environmental Engineering and Landscape Management, 28(1), 36-47. https://doi.org/10.3846/jeelm.2020.11832

$\mathrm{Xu}$, B., \& Lin, B. (2015a). Factors affecting carbon dioxide (CO2) emissions in China's transport sector: A dynamic nonparametric additive regression model. Journal of Cleaner Production, 101, 311-322. https://doi.org/10.1016/j.jclepro.2015.03.088

$\mathrm{Xu}, \mathrm{B} .$, \& Lin, B. (2015b). How industrialization and urbanization process impacts on CO2 emissions in China: Evidence from nonparametric additive regression models. Energy Economics, 48, 188-202. https://doi.org/10.1016/j.eneco.2015.01.005

Yildirim, E., Saraç, Ş, \& Aslan, A. (2012). Energy consumption and economic growth in the USA: Evidence from renewable energy. Renewable and Sustainable Energy Reviews, 16(9), 6770-6774. https://doi.org/10.1016/j.rser.2012.09.004

Yoon, H., \& Heshmati, A. (2020). Do environmental regulations affect FDI decisions? The pollution haven hypothesis revisited. Science and Public Policy, 48(1), 122-131. https://doi.org/10.1093/scipol/scaa060

Zakarya, G., Mostefa, B., Abbes, S., \& Seghir, G. (2015). Factors Affecting CO2 Emissions in the BRICS Countries: A Panel Data Analysis. Procedia Economics and Finance, 26, 114-125. https://doi.org/10.1016/s2212-5671(15)00890-4

Zerbo, E. (2015, January 28). CO2 emissions, growth, energy consumption and foreign trade in Sub-Saharan African countries. https://hal.archives-ouvertes.fr/hal01110769

Zhang, C., \& Zhou, X. (2016). Does foreign direct investment lead to lower CO 2 emissions? Evidence from a regional analysis in China. Renewable and Sustainable Energy Reviews, 58, 943-951. https://doi.org/10.1016/j.rser.2015.12.226

Zhou, Y., Fu, J., Kong, Y., \& Wu, R. (2018). How Foreign Direct Investment Influences Carbon Emissions, Based on the Empirical Analysis of Chinese Urban Data. Sustainability, 10(7), 2163. https://doi.org/10.3390/su10072163 